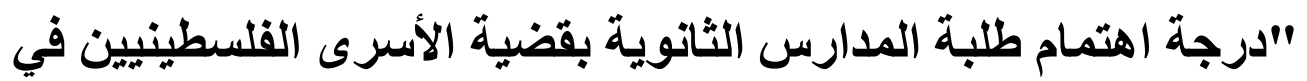

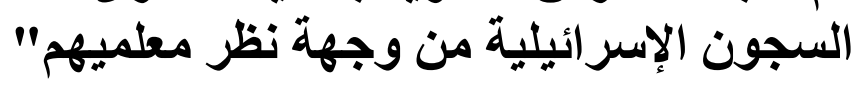

$$
\begin{aligned}
& \text { الباحث/د. دبد القادر خالد أبو علي } \\
& \text { الباحث/ د. منير حسن شقوره }
\end{aligned}
$$


هدفت التعرف إلى درجة الهمام طلبة المدارس الثانوية في محافظات غزة بقضية الأسرى

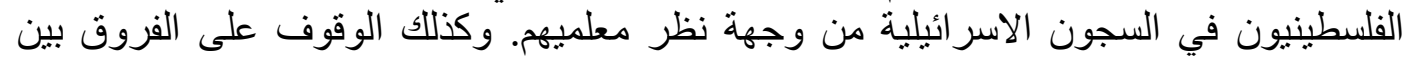

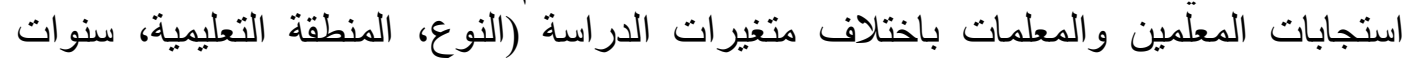

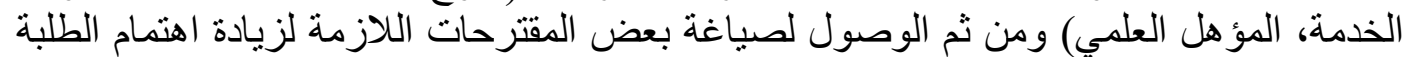

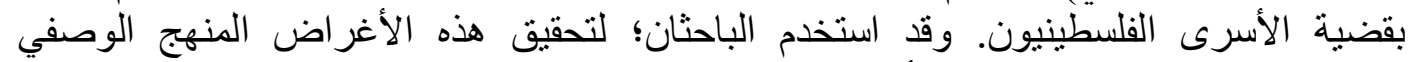

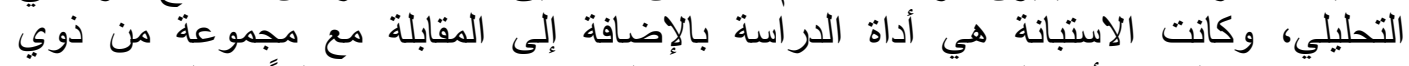

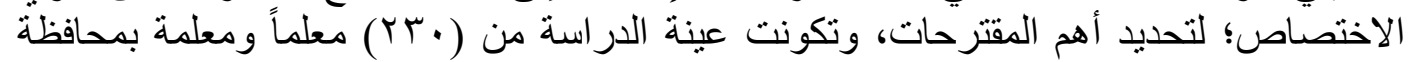

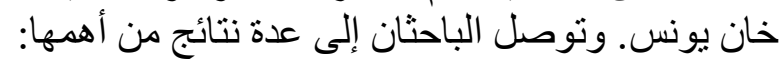

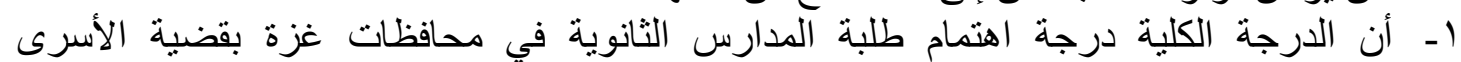

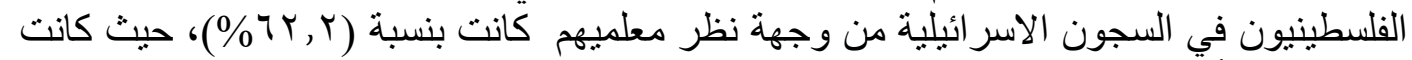

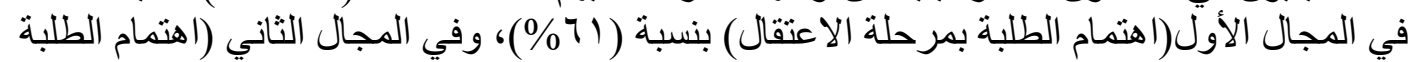

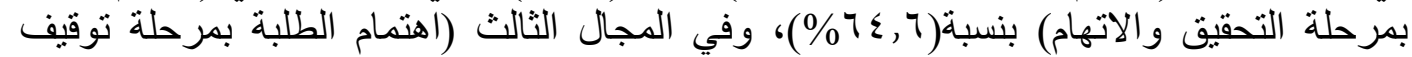

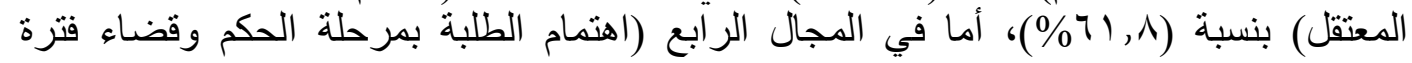

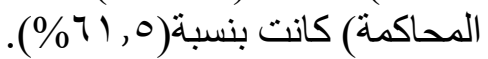

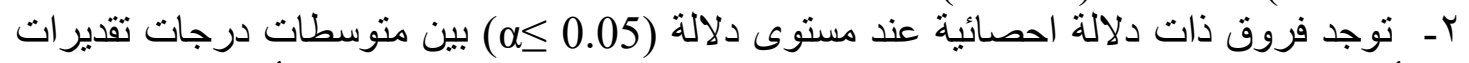

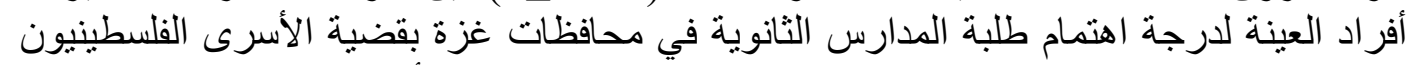

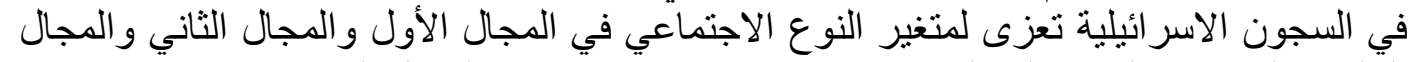

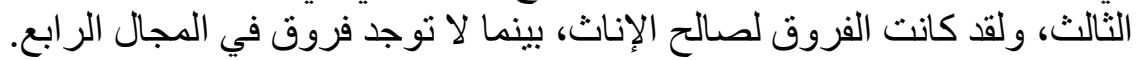

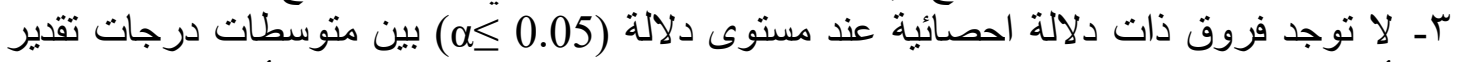

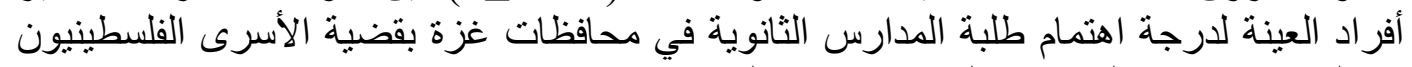

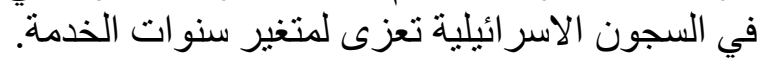

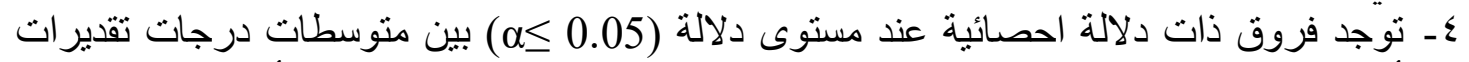

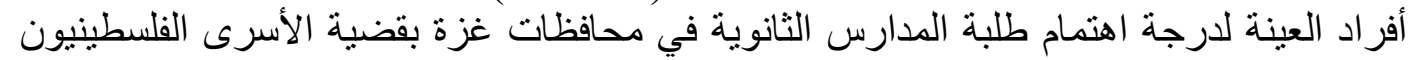

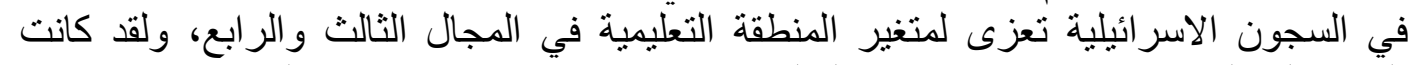

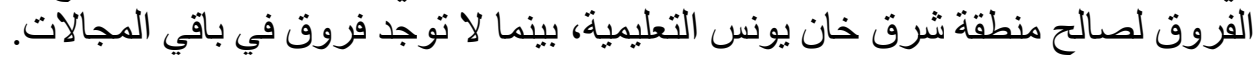

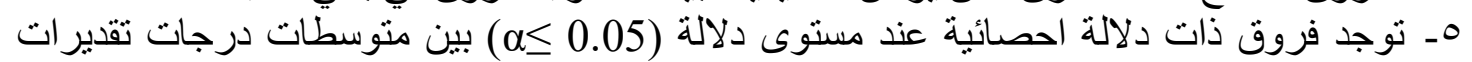

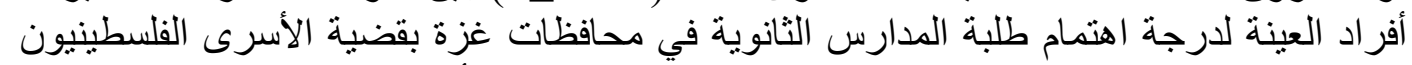

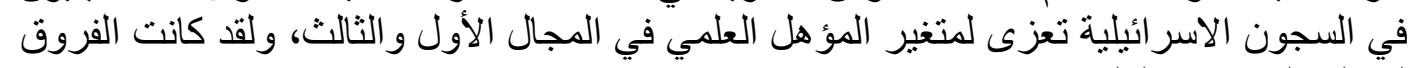
لصَّالح الدر اسات العليا.

\section{Summary of the study:-}

This study aimed to identify the degree of interest of high school students in the provinces of Gaza, for the issue of Palestinian prisoners in Israeli jails, from the standpoint of their teachers. As well as identify the differences between the responses of teachers according to the study variables (type, school district, years of service, qualification) and then access to the formulation of some of the proposals needed to increase students' interest in the issue of Palestinian prisoners. The researchers used; to achieve these purposes descriptive analytical approach, and the questionnaire is the study tool, in addition to the interview with a group of specialists; to identify the most important proposals, the study sample 
consisted of 230 male and female teachers in Khan Younis province. The researchers found several results, the most important was:-

1- The total score degree of interest at high school students in the Gaza

Strip for the issue of Palestinian prisoners in Israeli jails, from the viewpoint of teachers was increased (62.2\%), where it was in the first domain (students 'interest to the stage of arrest) by (61\%) and in the second domain (students' interest to the stage of investigation and indictment) $(64.6 \%)$ and in the third domain (students 'interest to the stage of arrest detainee) (61.8\%) in the fourth domain (students' interest to the judgment stage and spend the duration trial) was $(61.5 \%)$.

2 - There are statistically significant differences at the level of significance $(0.05 \geq \alpha)$ between the mean scores of the estimates of the sample to the degree of interest of at high school students in the provinces of Gaza, for the issue of Palestinian prisoners in Israeli jails, due to the variable of gender in first domain , second domain and third domain and have been differences in favor of females, while there were no differences in fourth domain.

3- There are no statistically significant differences at the level of significance $(0.05 \geq \alpha)$ between the mean scores of the estimates of the sample to the degree of interest of at high school students in the provinces of Gaza, for the issue of Palestinian prisoners in Israeli jails, due to the variable of servant years.

4 - There are statistically significant differences at the level of significance $(0.05 \geq \alpha)$ between the mean scores of the estimates of the sample to the degree of interest of at high school students in the provinces of Gaza, for the issue of Palestinian prisoners in Israeli jails, due to the variable school district in the third ,and fourth domain; the differences have been in favor of the east of KhanYounis educational, while there are no differences in other areas.

5 - There are statistically significant differences at the level of significance $(0.05 \geq \alpha)$ between the mean scores of the estimates of the sample to the degree of interest of at high school students in the provinces of Gaza, for the issue of Palestinian prisoners in Israeli jails, due to the variable qualification in the first, and third domain ; the differences have been in the favor of advanced studies. 


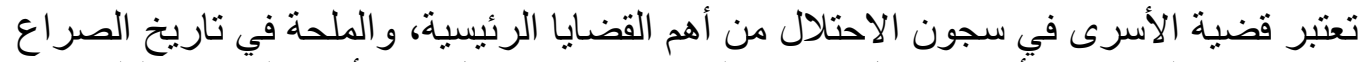

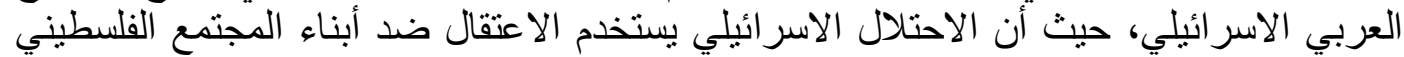

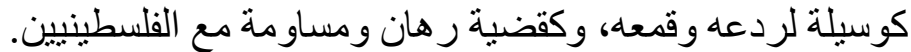

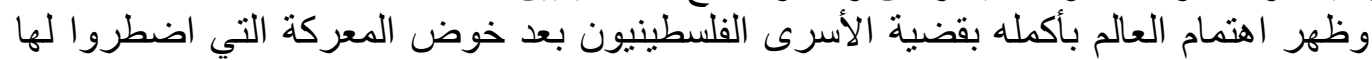

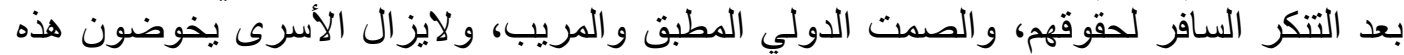

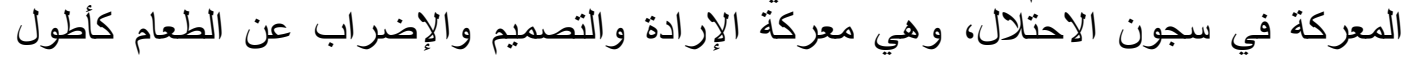

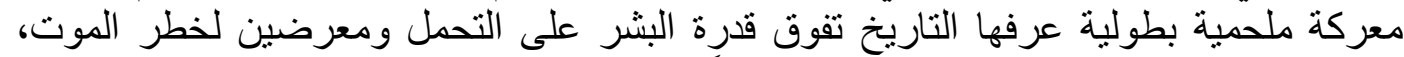

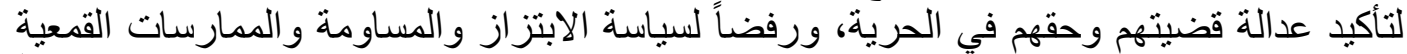

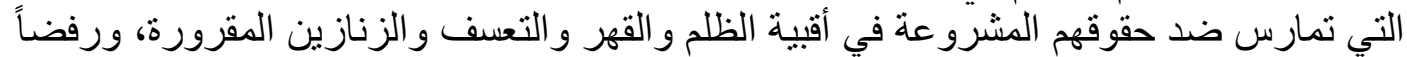

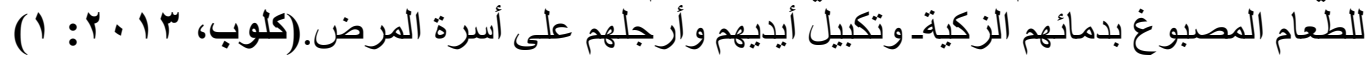

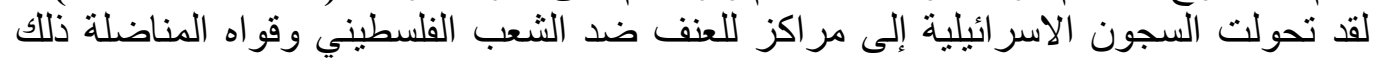

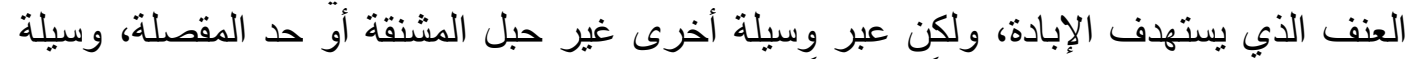

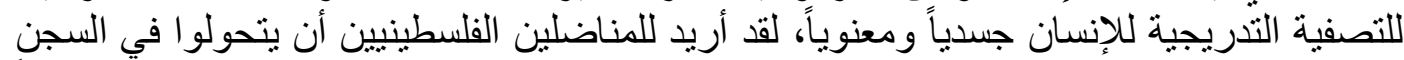

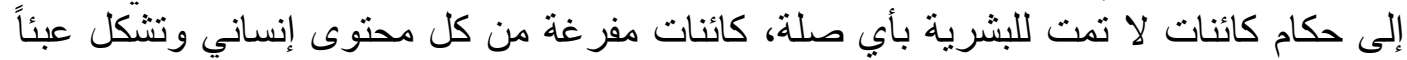

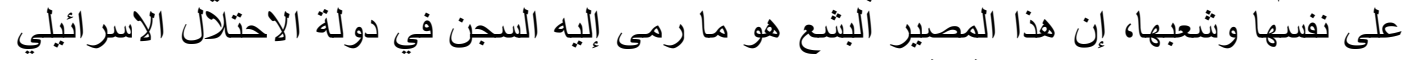

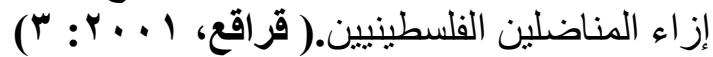

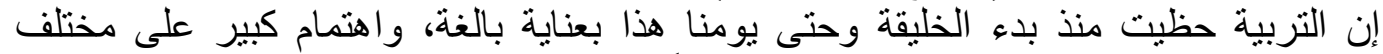

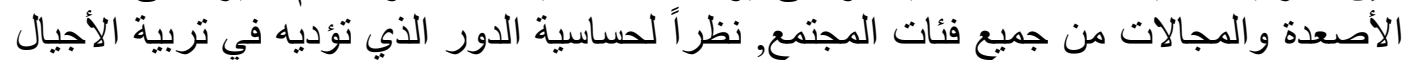

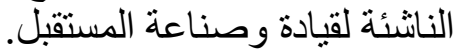

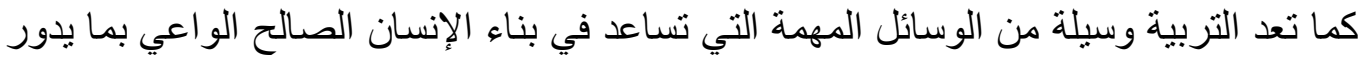

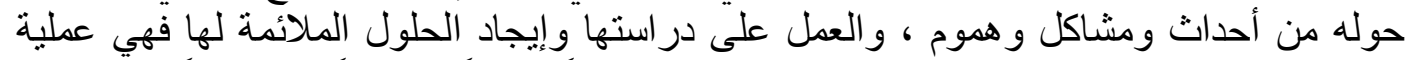

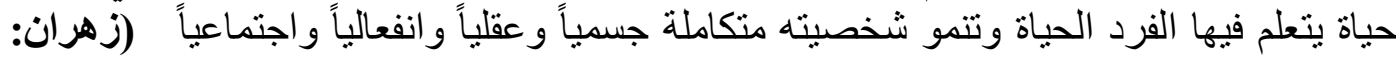

(Y. 6 ) $9 V \mathrm{~V}$

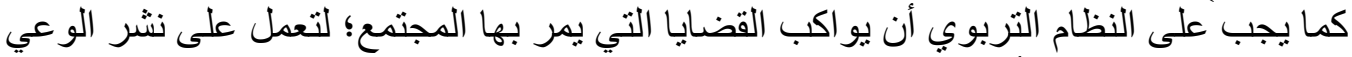

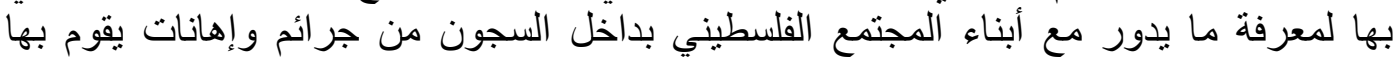

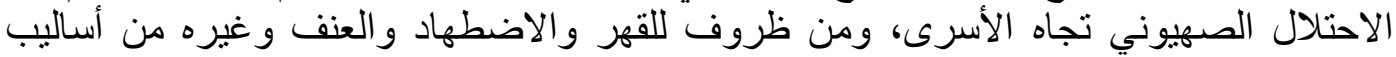

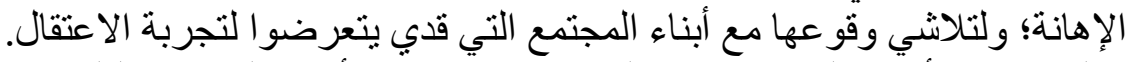

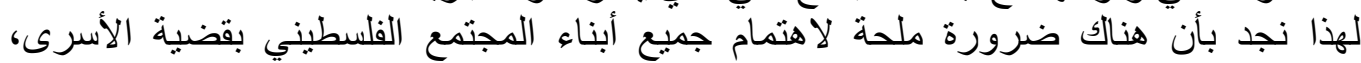

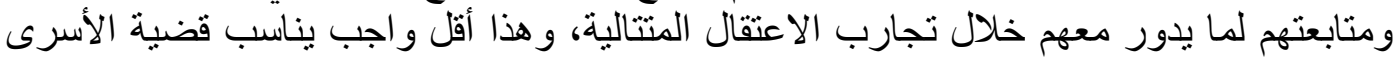
وحجمها في المجتمع الفلسطيني. وفي هذه الدر اسة يركز الباحثنان على عينة هامة في المجتمع وهم طلبة المدارس الثانوية أي سن

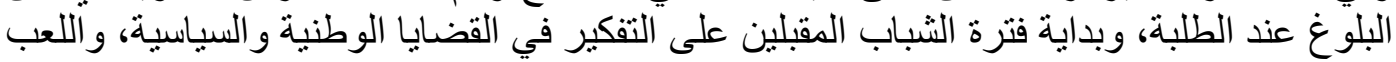

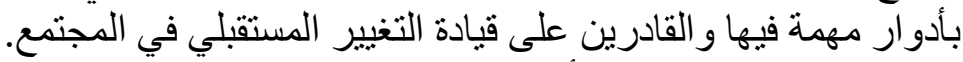

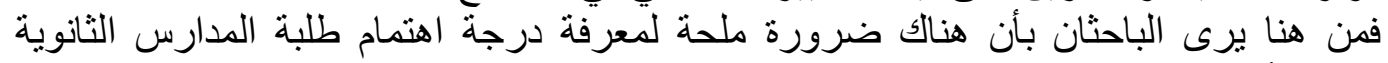

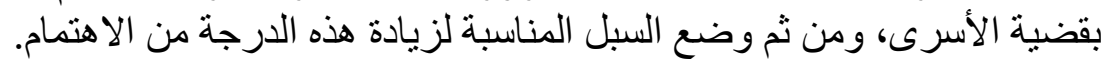

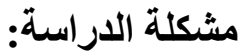

سعت الدراسة للإجابة عن الأسئلة التالية: ا - ما درجة اهنمام طلبة المدارس الثانوية بقضية الإنة الأسرى الفلسطينيين في السجون الإسرائيلية 
بـ - هل توجد فروق ذات دلالة إحصائية بين متوسطات تقدير ات أفر اد عبنة الدر اسة درجة اهتمام

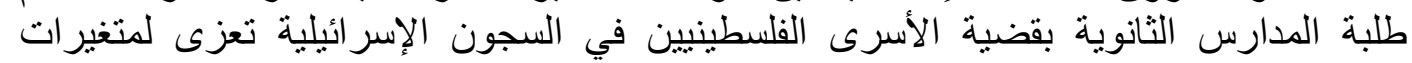

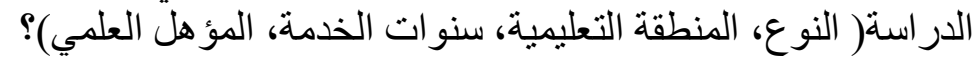

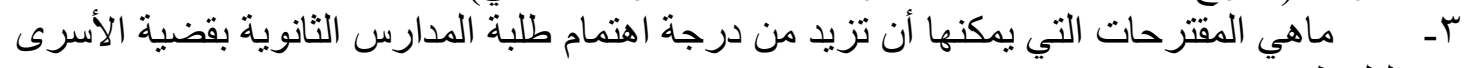
الفلسطينيين?

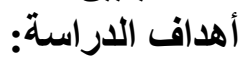

ـ - التعرف إلى درجة اهتمام طلبة المدارس الثانوية بقضية الأسرى الفلسطينيين في السجون

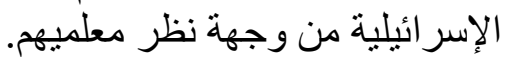

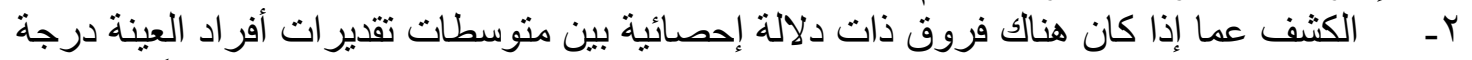

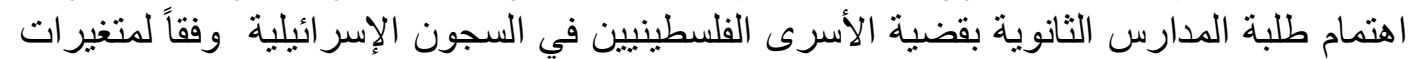

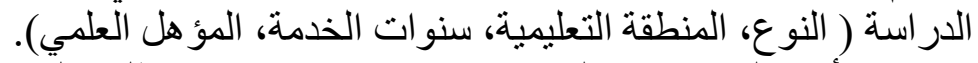

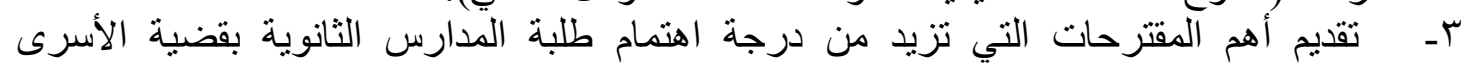
الفلسطينيين في السجون الإسرائيلية. أهمية الدراسةتة

ا - قد تركز هذه الدر اسة على موضوع هام في المجتمع الفلسطيني وهو الأسري الفلسطينيون في

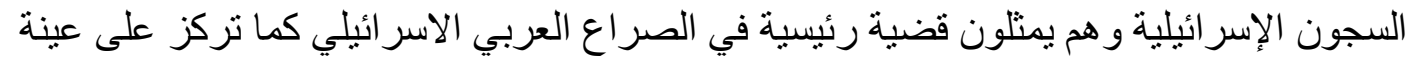
مهمة في الميدان التربوي وهم طلبة المدارس الثنانوية. r- - قد تساعد هذه الدر اسة في تشريب النظام التربوي بما يتضمنه من أنشطة لاصفية و مقررات

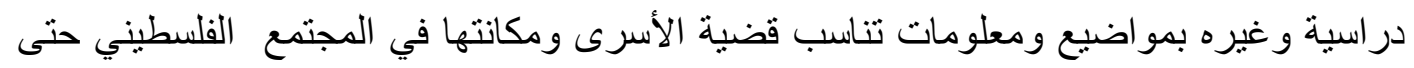

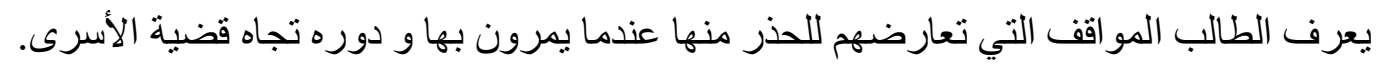

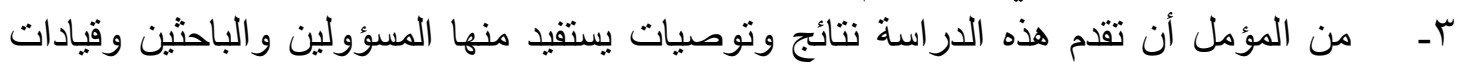
النظام التربوي في معرفة واقع ثقافة قضية الأسرى لدى طلبة المرحلة الثانوية وذللك لمحاولة سد التد

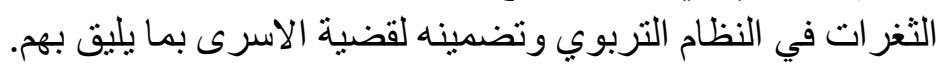

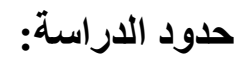

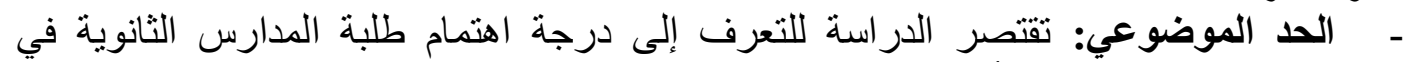

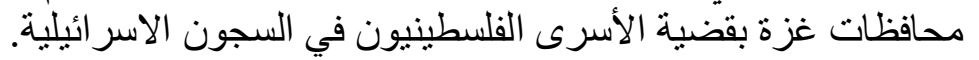

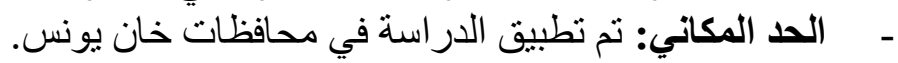

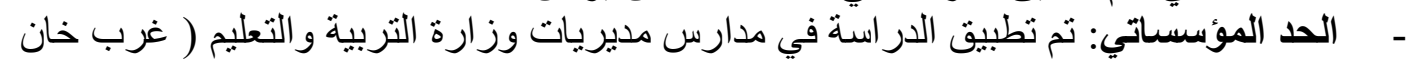
ليو نس وشرق خان يونس). - الحد البشري: تم تطبيق الدراسة على معلمي ومعلمات المدارس الثانوية في محافظة خان مصطات الداث. الدراسة: يعرف الباحثان المصنطات الدات إجرائياً كما يلي: - ملبة المدارس الثانوية: " الطلاب والطالبات في الصفوف العانون الحادي عثر والثاني عثر حسب تقسيم وزارة التربية و التعليم العالي الفلسطينية." البطئ.

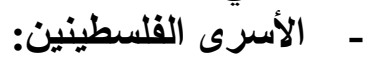
"المعتقلون الفلسطينيون في السجون الاسر ائيلية والذين اعتقلو الفلى بد قوات الاحتلال الصهيوني

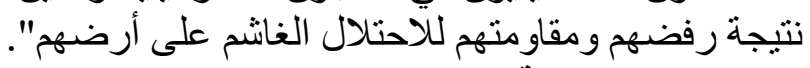

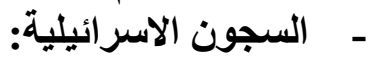




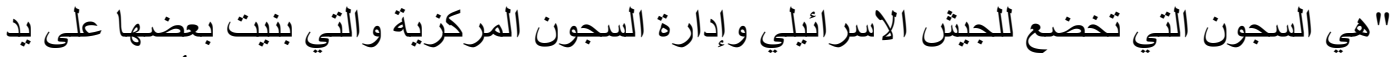

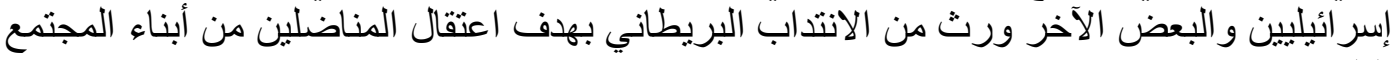

الفلسطيني."

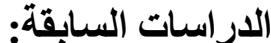

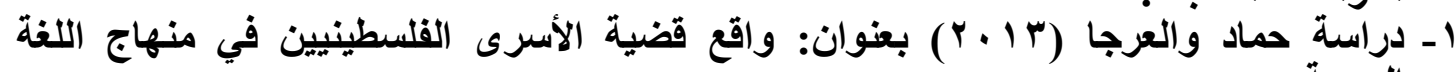
العربية. هدفت هذه الدراسة التعرف إلى مدى تناول مناهج اللغة العربية لقضية الأسرى الفلسطينيين,

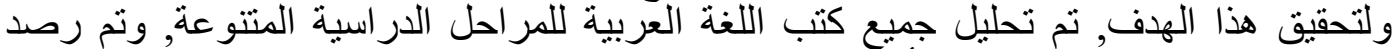
المواضيع التي تناولت قضية الأسرى في مقررات المراحل الدراسية المتنوعة. وبعد التهد التحليل

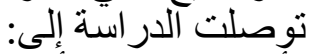

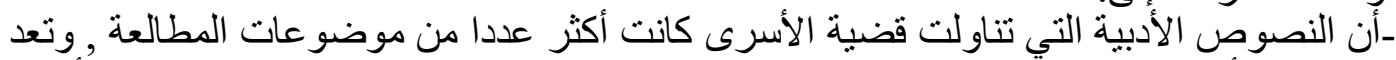

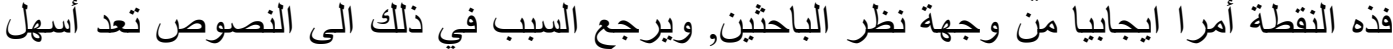

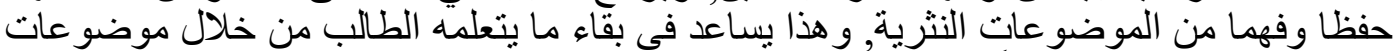

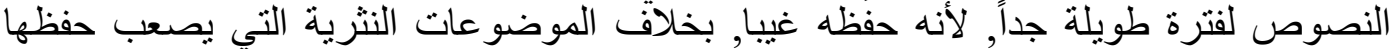

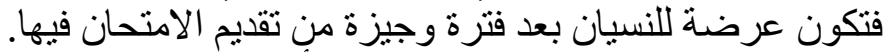

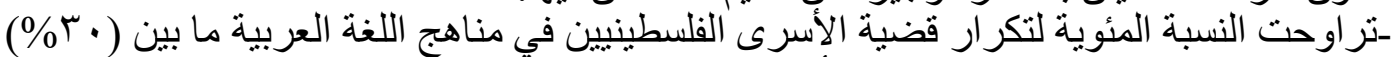

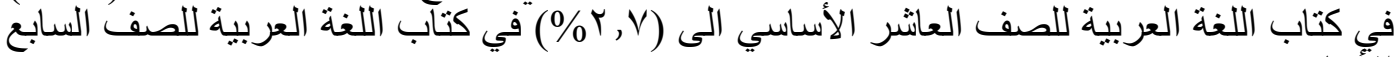

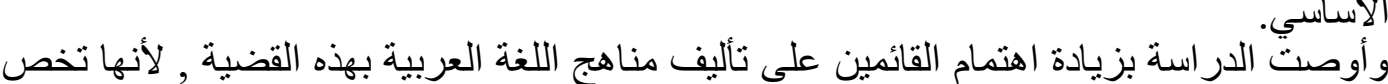

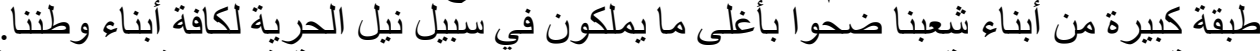

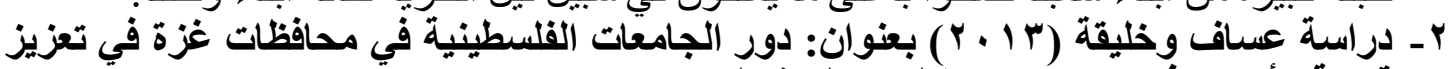

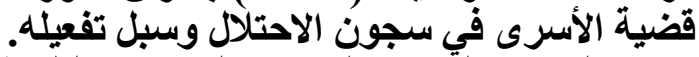

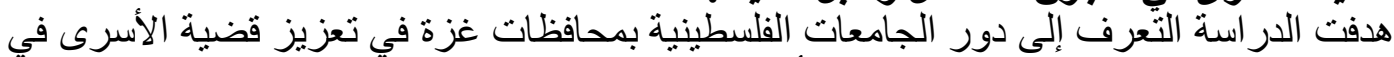

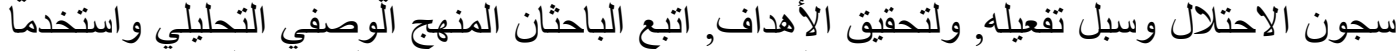

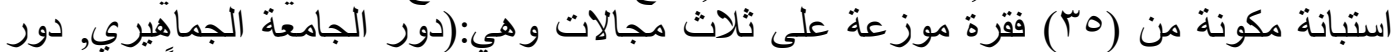

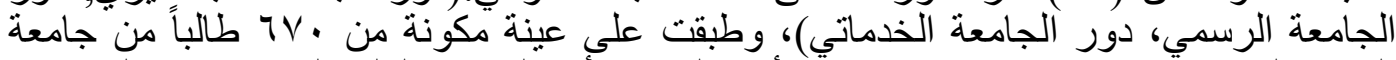

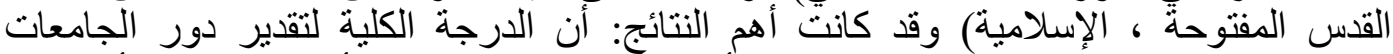

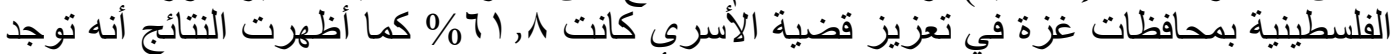

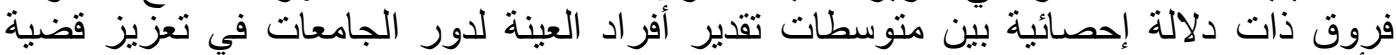

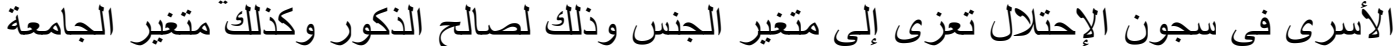

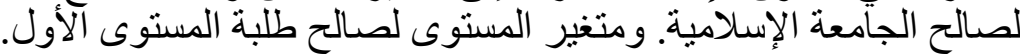

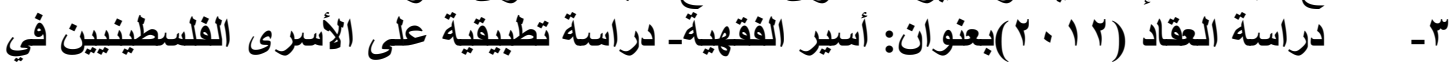

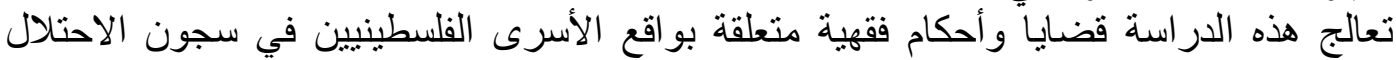

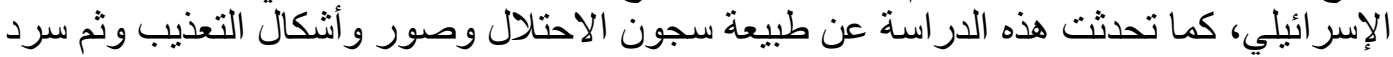

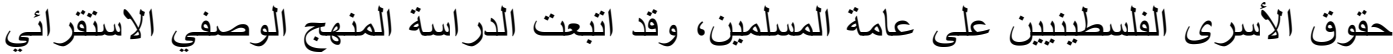

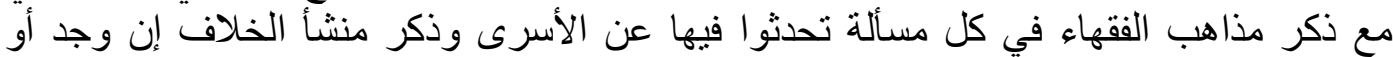
استنباطه. وتوصلت الدراسة إلى عدة نتائج أهمها: يتعرض الأسير الفلسطيني في مرحلة التحقيق

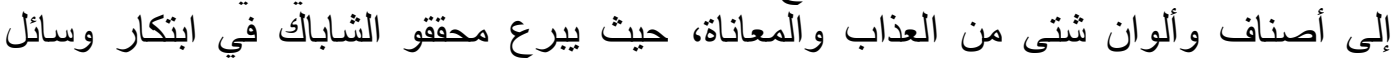

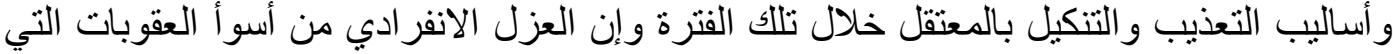

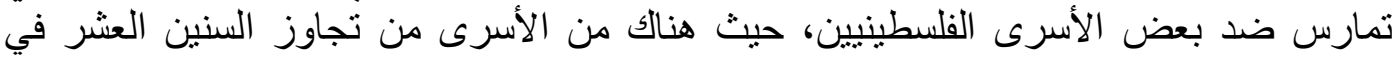

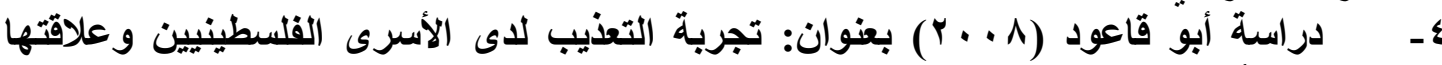
بالتفكير الأخلاقي. 
هدفت هذه الدراسة إلى الكثف عن أثر التعذيب الذي تعرض له الأسرى المحررين في سجون

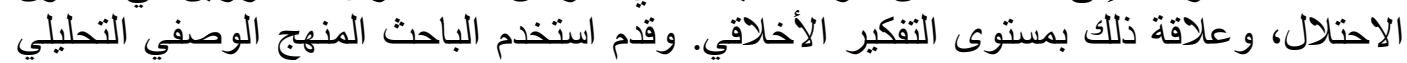

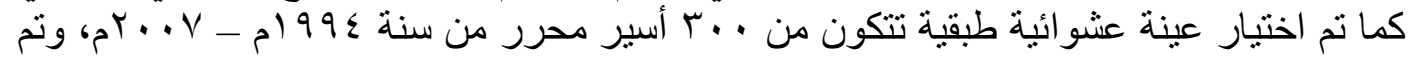

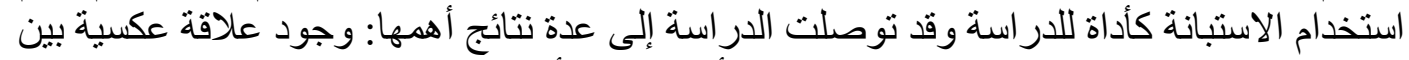

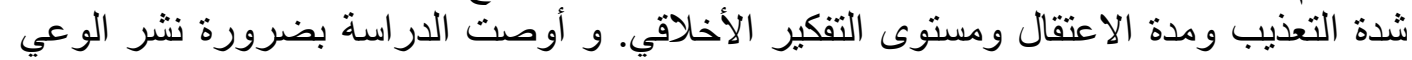

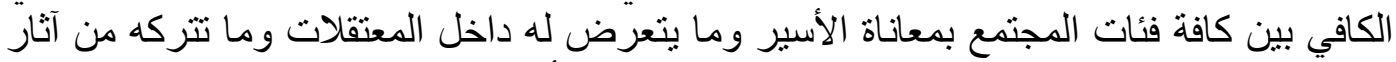

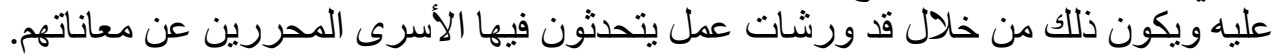

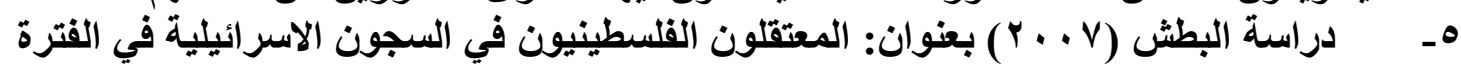

. $910-197 \vee$

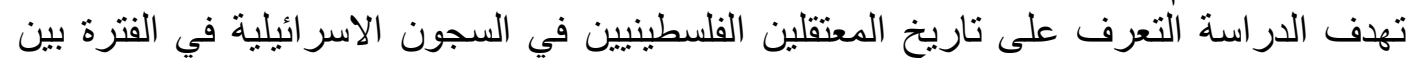

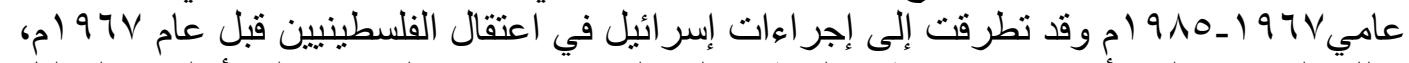

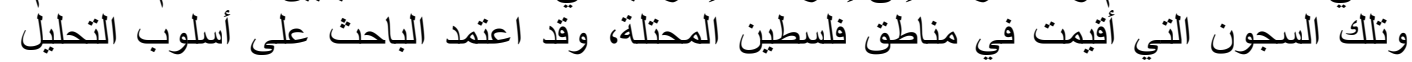

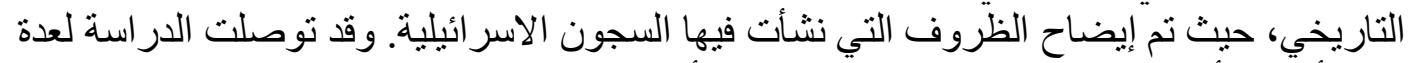

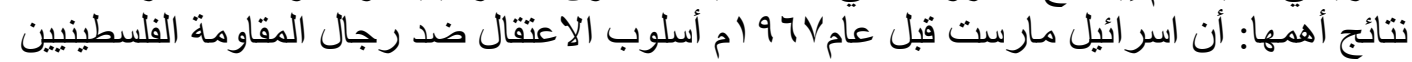

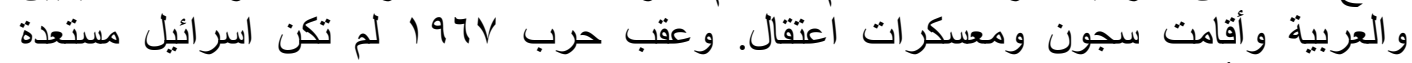

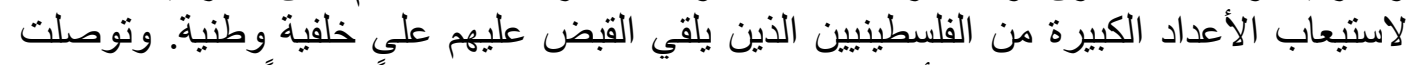

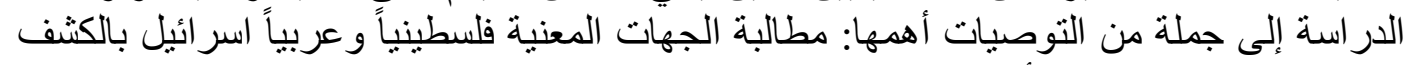

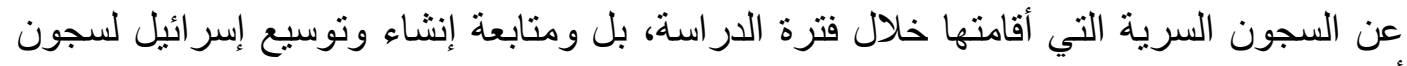

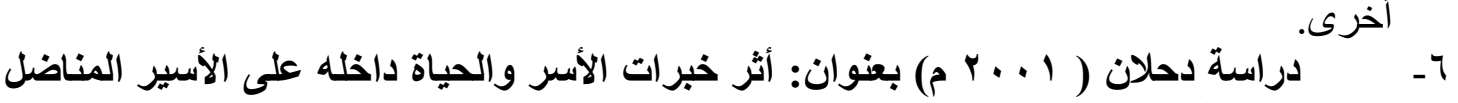
والجندي النظامي. هدفت ألتعرف إلىى أثر خبرات الأسر على الأسير المناضل والجندي النظامي. وتكونت عينة

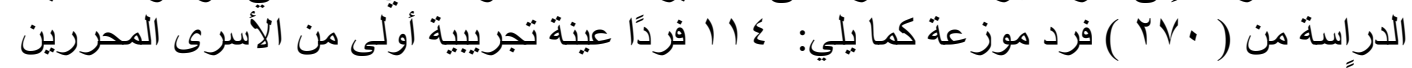
حديثًا

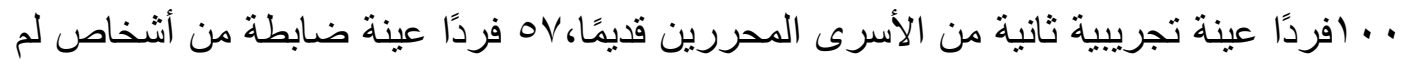

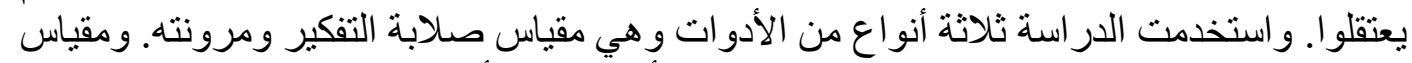

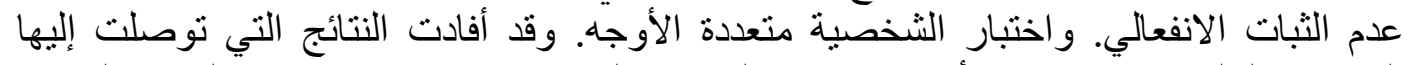

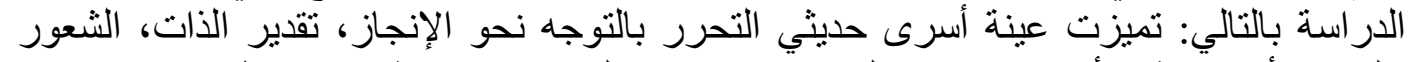

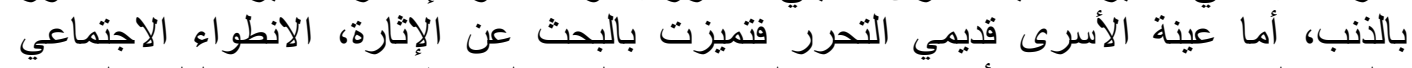

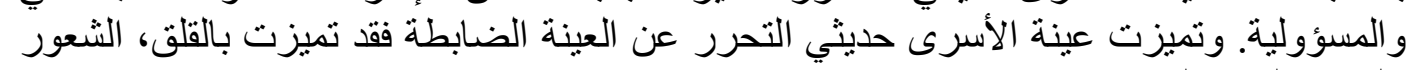
بالذنب، المسؤولية.

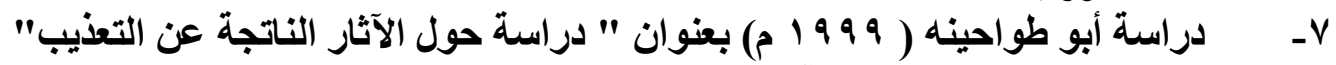

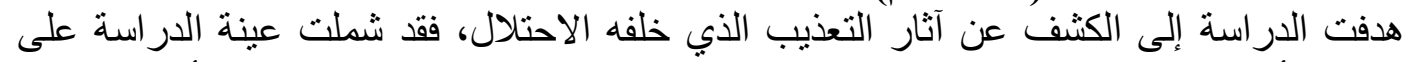

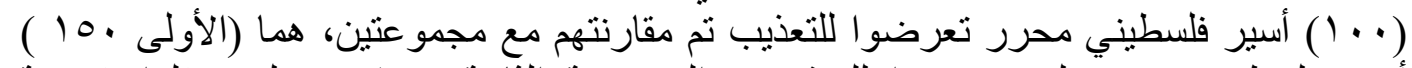

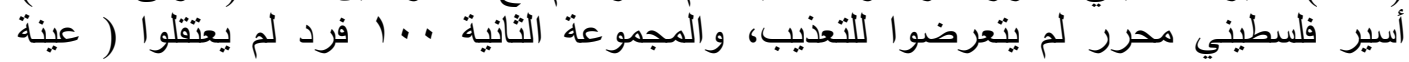

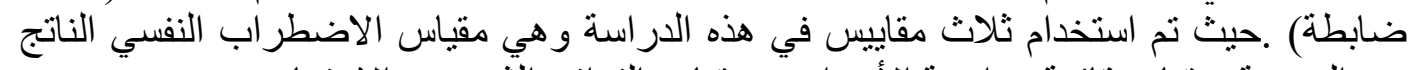

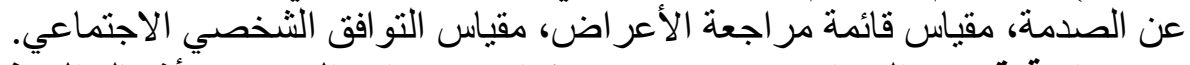

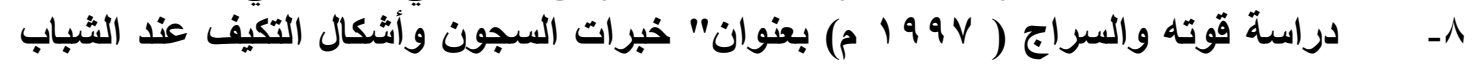

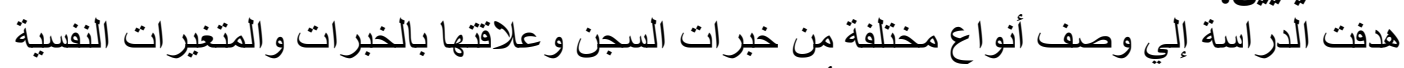

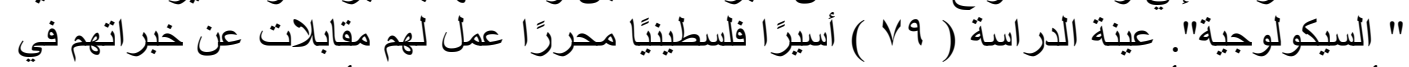

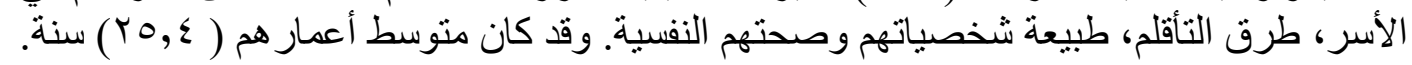




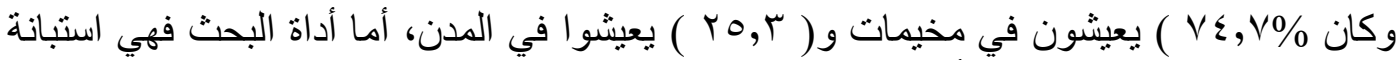

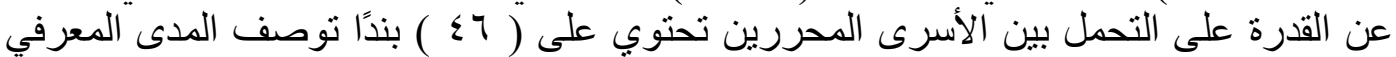

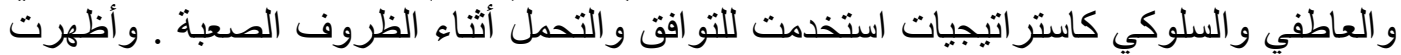

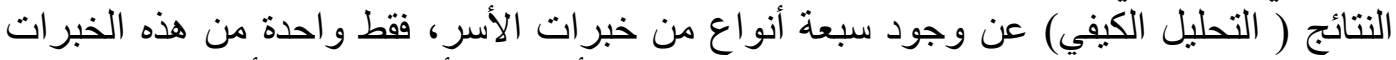

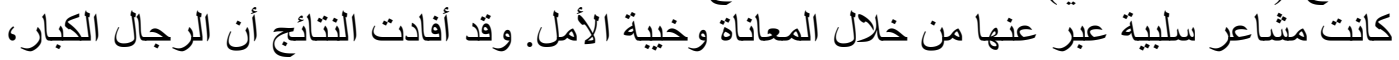

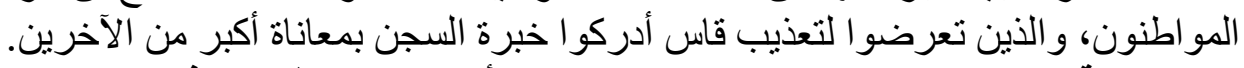

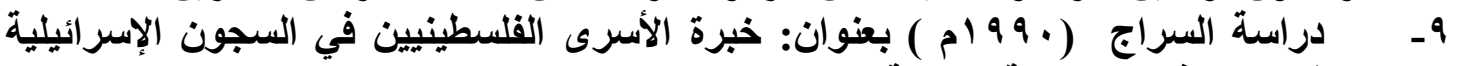
وعلاقتها بالتعذيب والصحة الصحة النفسية: هدفت الدراسة التعرف إلى خبرة الأسرى الفلسطينيين في السجون الاسر ائيلية و علاقتها بالتعذيب

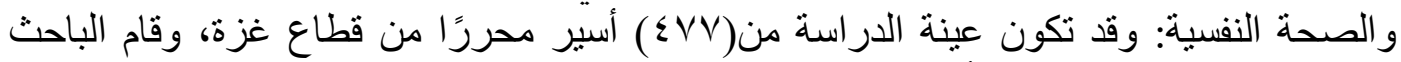

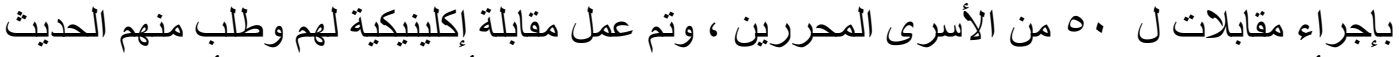

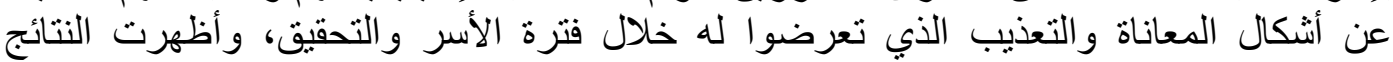

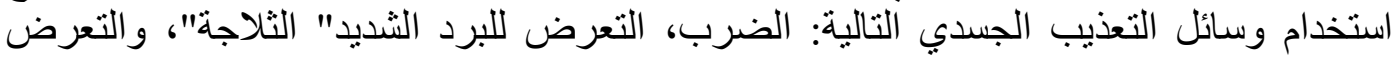

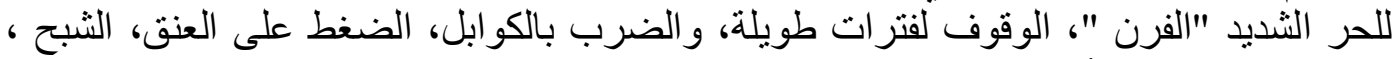

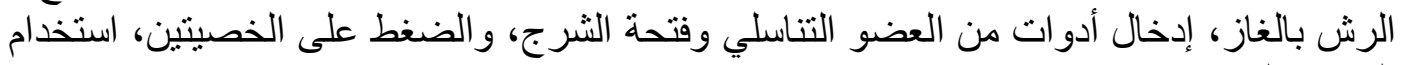
الصعق الكهربائي.

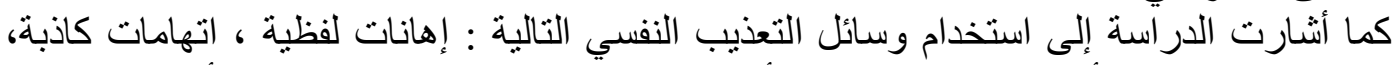

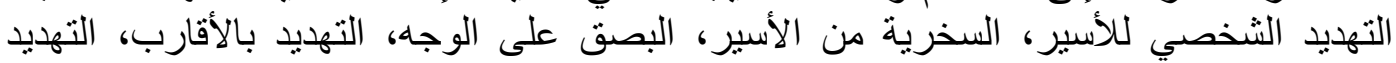

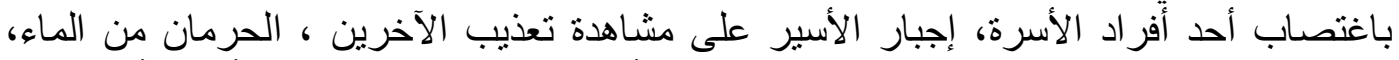

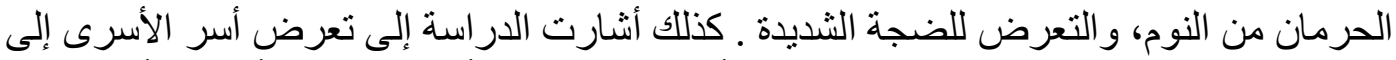

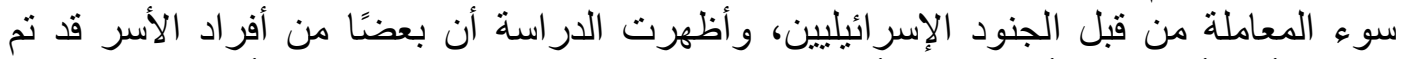

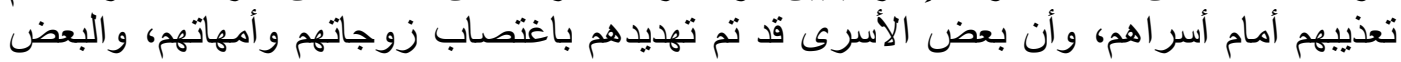

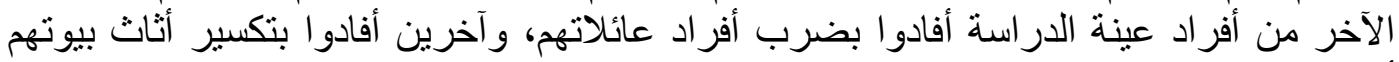

أثناء عملية الاعتقال تعقيب على الاراسـات السابقة:

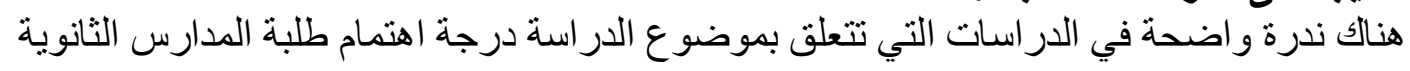

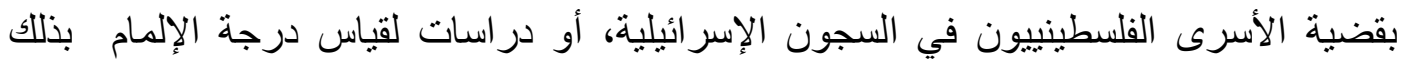

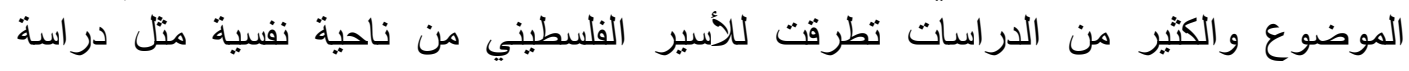

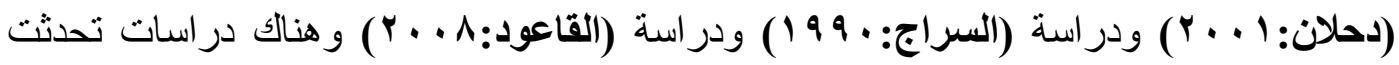

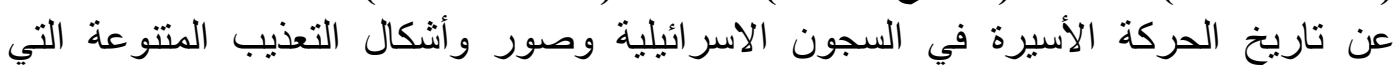

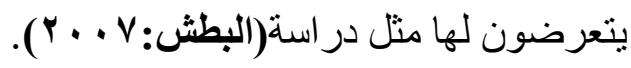
اتفقت الدر اسة الحالية مع بعض الدر اسات السابقة في استخدام المنهج الوصفي التحليلي مثل در اسة استة

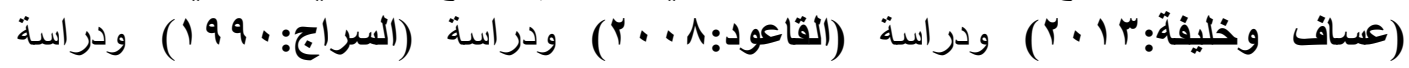

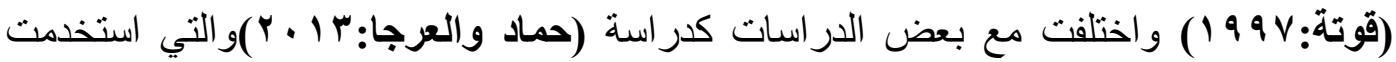

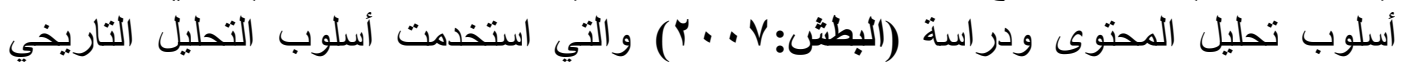

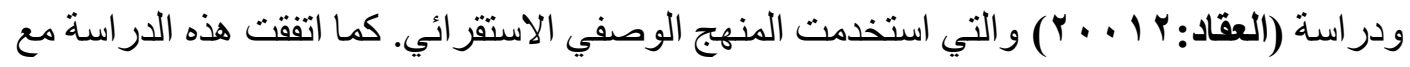

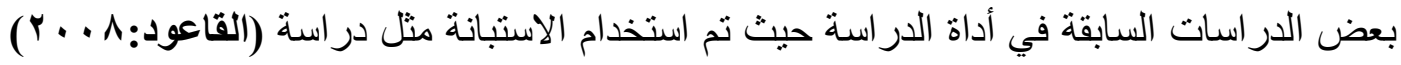

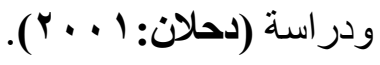
- استفاد الباحثان من عرض الدراسات السابقة في عدة جوانب منها: بناء أداة الدراسة واستخدام

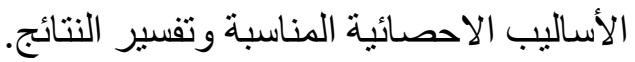


- تعتبر هذه الدراسة من أوائل الدراسات الفلسطينية على حد علم الباحثين التي تبحث في درجة

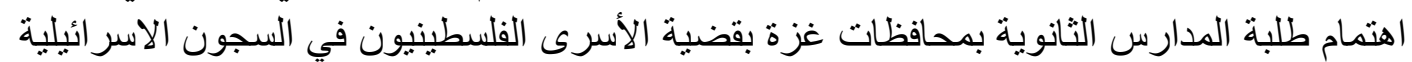

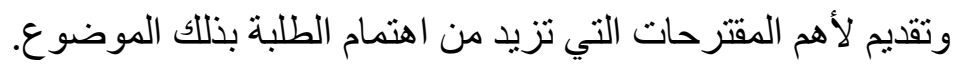

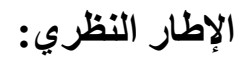

تعتبر قضية الأسرى الفلسطينيين من القضايا الهامة في المجتمع الفلسطيني، بل من أهم القضايا

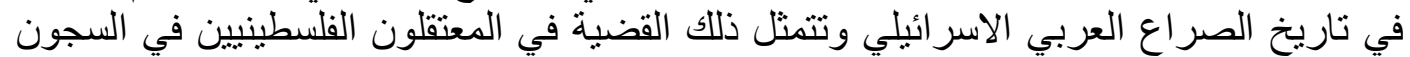
الاسر ائيلي، حيث أن الاحتلال الاسر ائيلي يستخدم الاعتقال ضد أبناء البناء المتمع الفلسطيني كوسيلة

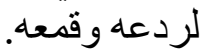
و الأسر ظاهرة تاريخية وجدت منذ فجر التاريخ، تستخدمها السلطات القائمة على النظام الحاكم.

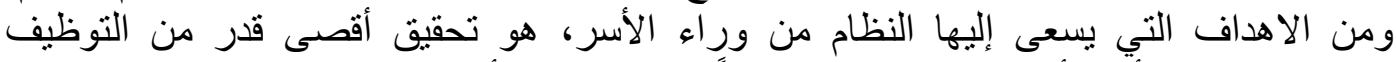

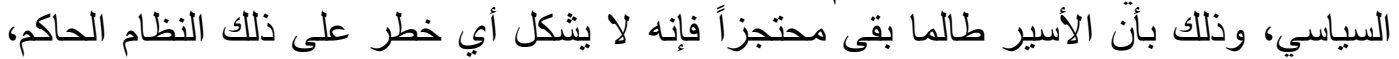

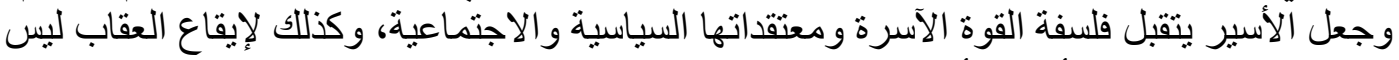

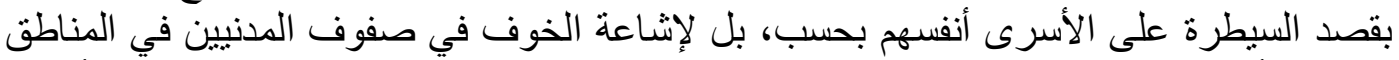

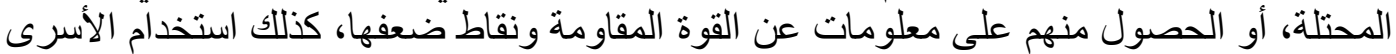

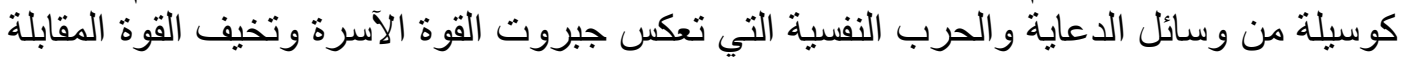

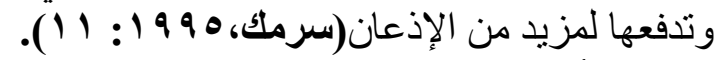

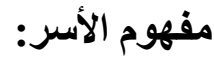

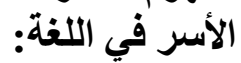
مأخوّذ من الإسار ، وهو القيد الذي يثد به الثئي، كالحبل و السلسلة. فيقال: أسره يأسره أسراً:

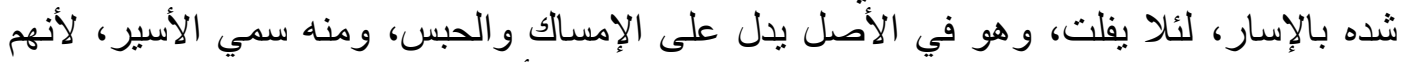

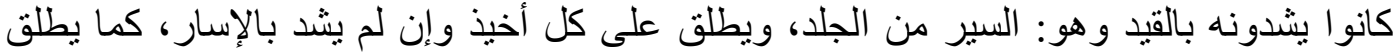

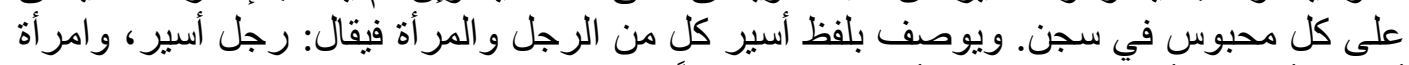

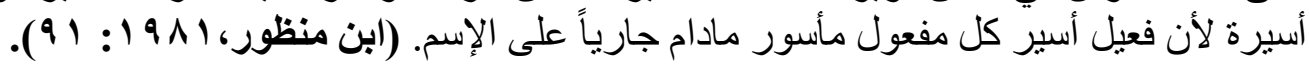

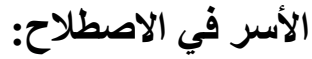
يعرف (سرمك، 990 19: 11) 11 الأسير بأنه شخص يتم أسره أو يعتقل من قبل قوة محاربة مناوئة

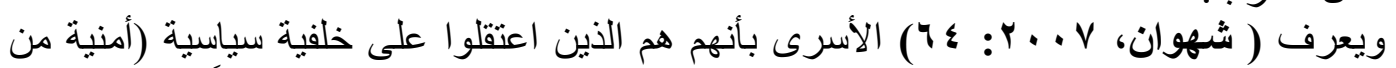

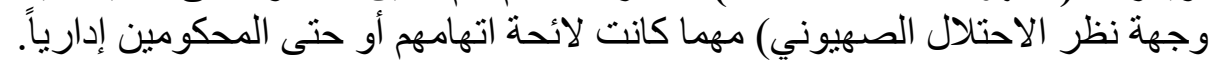

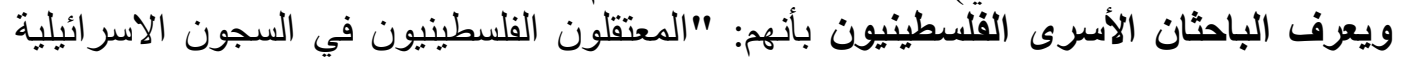
و الذين اعتقلوا على يد قوات الأيرى الاحتلال الصهيوني نتيجة رفضهم ومقاومتهم للاحتلال الغاثم على الألى

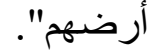

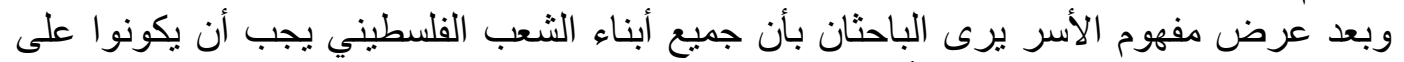

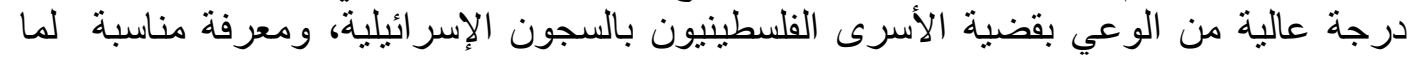

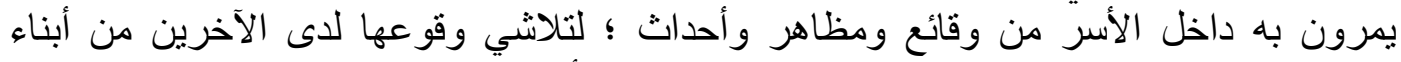

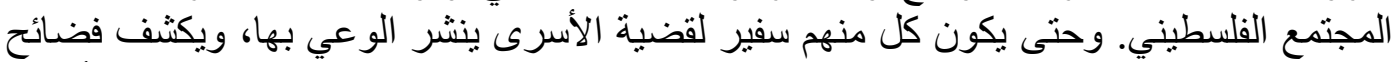

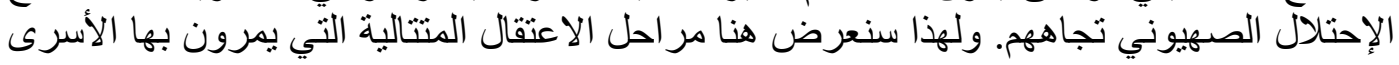
الفلسطينيون في السجون الاسر ائيلية.

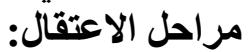

يعيش المعتقلون الفلسطينيون في السجون الاسرائلية أثنكالاً متنوعة للتعذيب والتنكيل

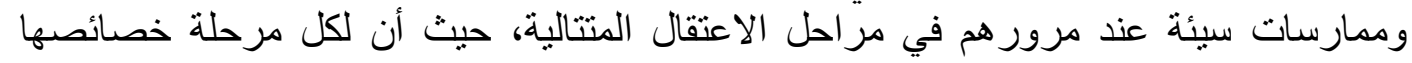


وأسالييها من قبل الاحتلال الاسرائلي وكل معتقل عندما يخرج من الأسر يكون قد مر بهذه

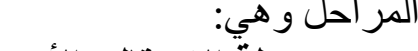

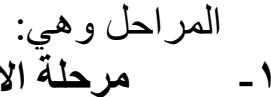

و هي الفترة التي تكون عند اعتقاله من البيت أو الثار عاعُ أو عبر المعابر أو الحواجز التي يسيطر

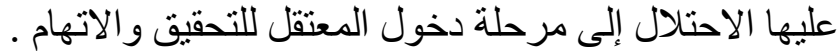
والاعتقال كما ذكرنا يكون من عدة مناطق ولكن الكن الغالب منها هو الاتهو الاعتقال من البيت ويقول

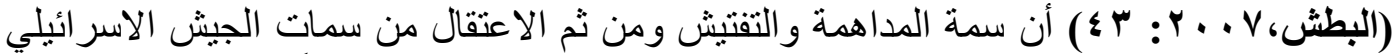

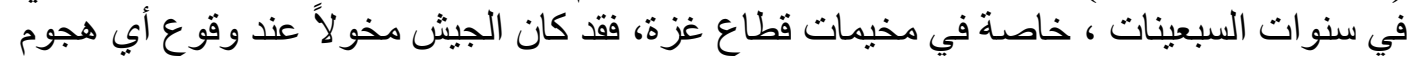

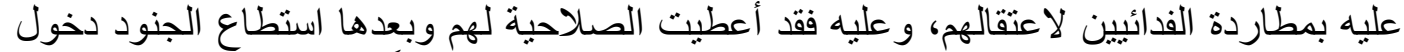

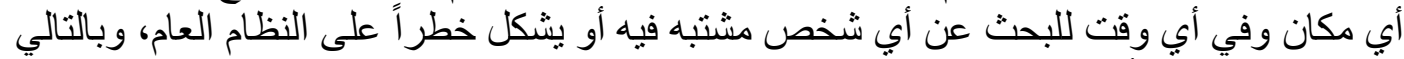
سمح ذللك باعتقال أعداد كبيرة من الفدائيين بعد حدوث عمليات هجوم على قو افل عسكرية تكون مارة من أمام مخيمات الباع ألاجئين.

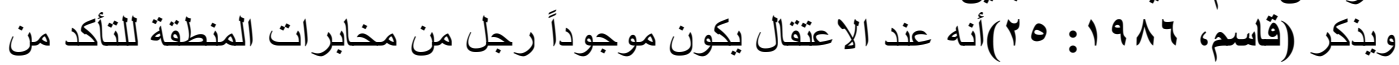

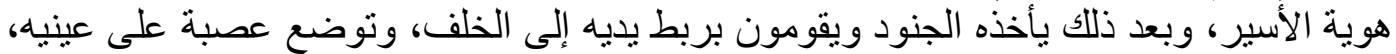

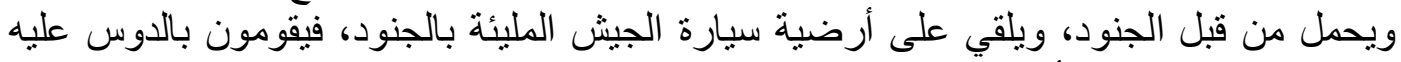

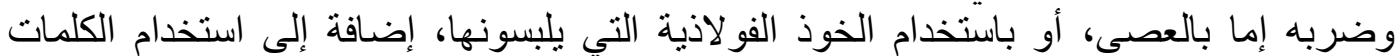

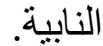
وبعد ذللك يتم ترحيل الأسير "المعتقل" من مكان اعتقاله إلى المعتقل حيث أنه يتعرض لثنى أنواع الإهانات و الركل و الضرب. و هناك بعض المعتقلين يتم ارسالهم بعد الاعتقال مباشرة إلى المعتقل والبعض الآخر يتم التجول به

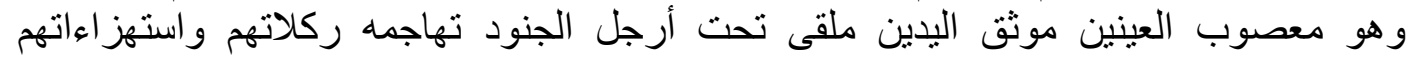

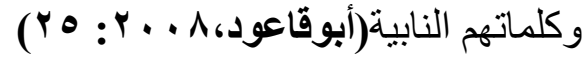

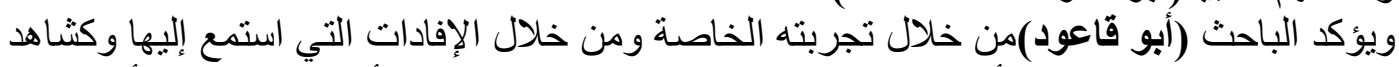

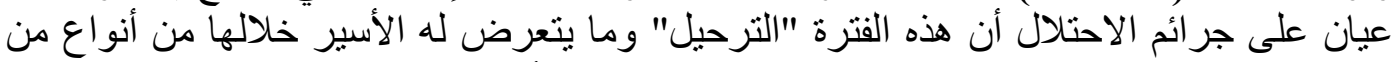

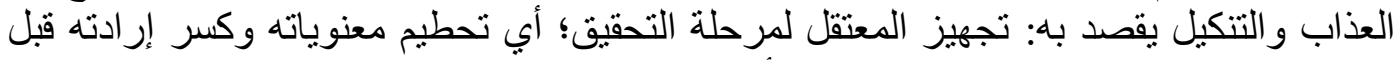

\section{وصوله للتحقيق لتكون مهمة ضابط التحقيق أكثر سهولة.}

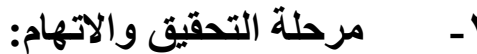

تعد هذه المرحلة من أهم مر احل الاعتقال وأخطر ها فهي تحدد مسار عملية الاعتقال وهي التي تحدد مدى نجاح إدارة السجون و أجهزة الأمن في جلب المعلومات ولإ وإضعاف الأسرى في تلبية وتبدأ مرحلة التحقيق في أغلب الأحيان من مكان اعتقال المتهم, و عليه فقد كان ضباط الجيش

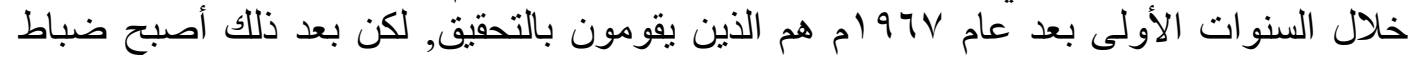

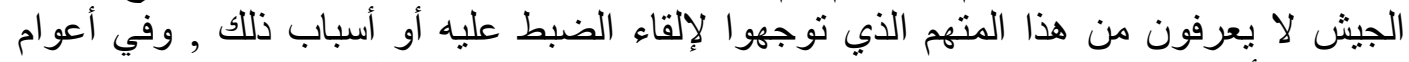

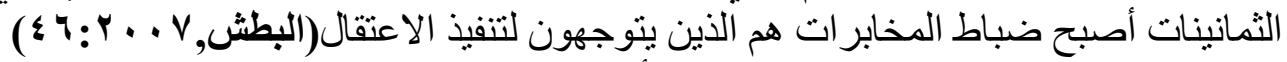

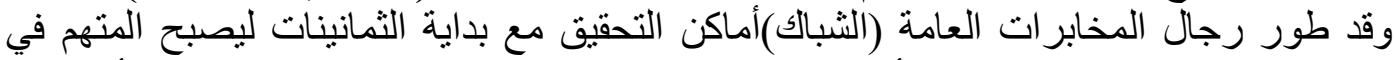

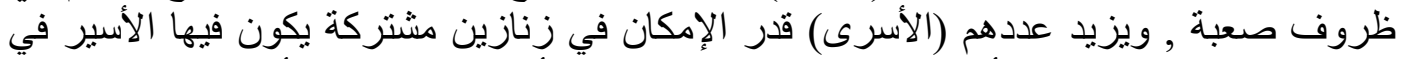

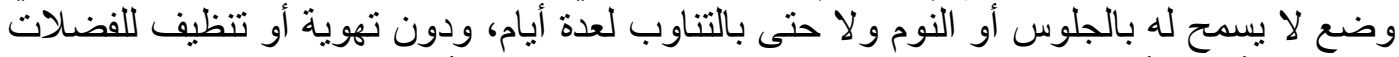

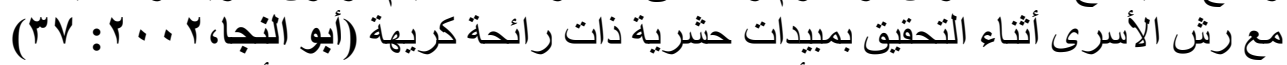

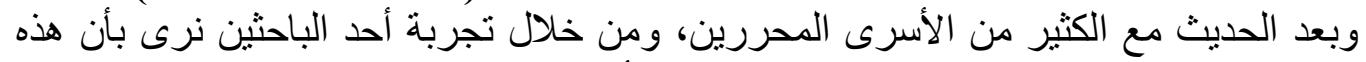

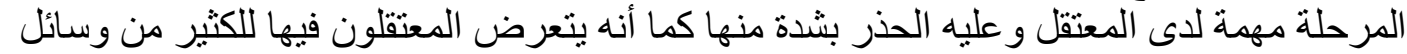

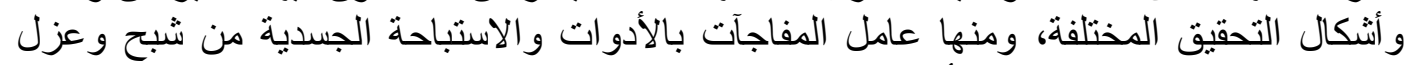

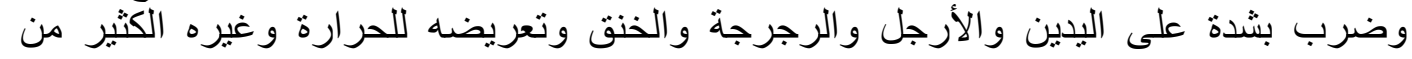


الأساليب الغير مسموح استخدامهاويرى الباحثان بأن هذا يعبر عن النفسية المريضة التي يتمتع بها

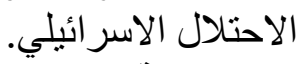

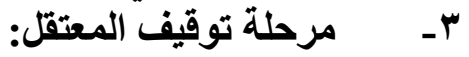

و هي قضاء المعتقل فترة زمنية قد تكون طويلة أو قصيرة وتكون بعد انتهاء مرحلة التحقيق إلى

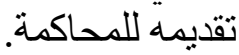
وفيها يتعرض لالأسير للترحيل من مكان الاعتقال إلى المحكمة، كلما جاء مو عد محكمتهاه وفي مني

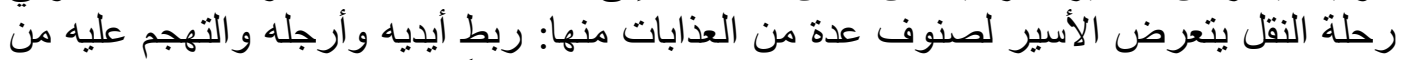

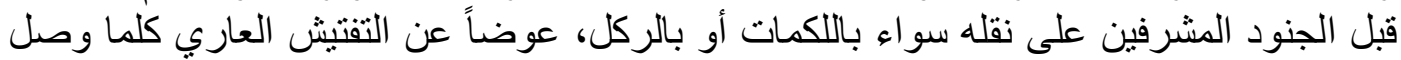

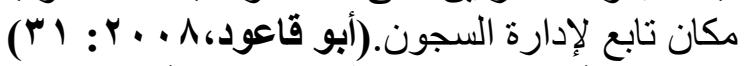

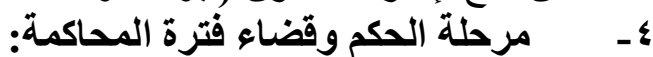

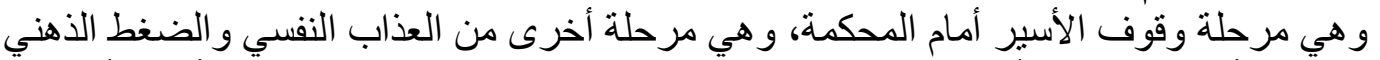

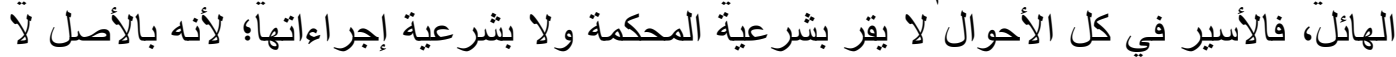

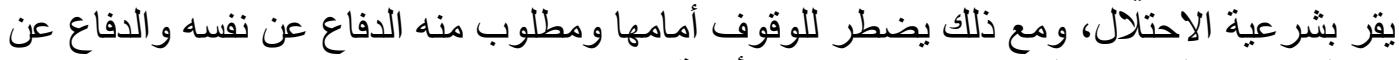

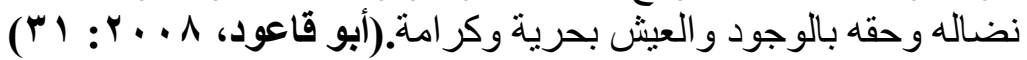

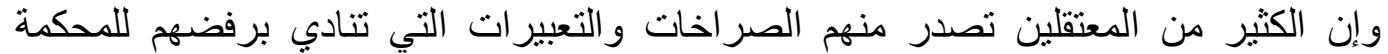

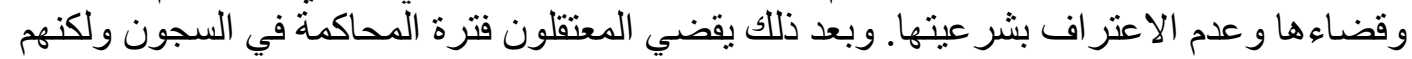

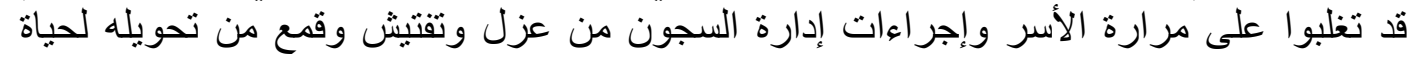
اجتماعية لها خصائصها الجميلة.

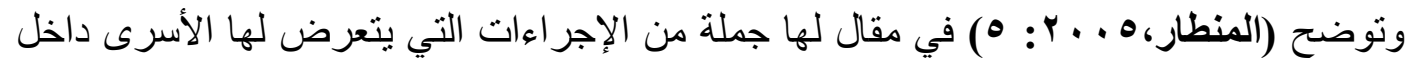

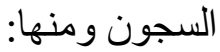
اللجوء لافتتاح أقسام جديدة جر اء تز ايد أعداد الأسرى.

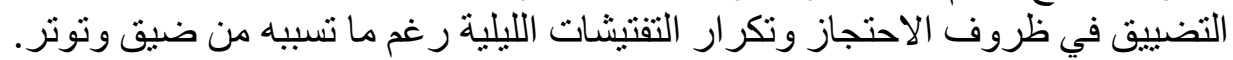

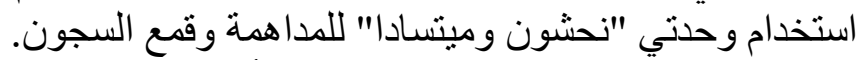
المغالاة في فرض الغراميات النمات المالية على الأسرى.

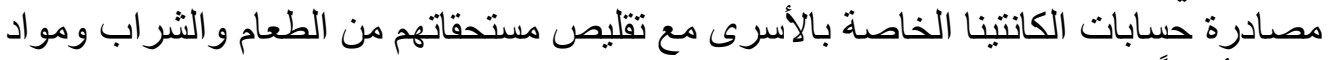

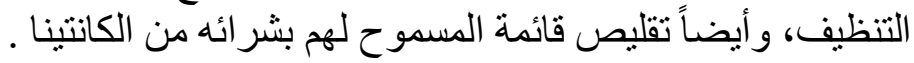

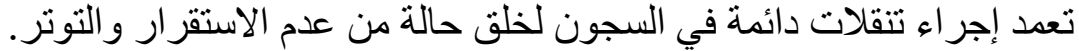

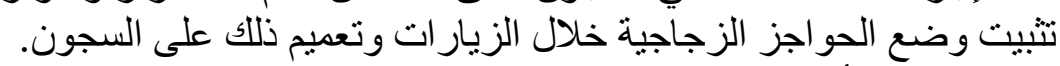
توسيع قائمة الأسرى الممنو عين من تلقي الزيارة الزيارة تو اصل العمل بسياسة الإهمال الطبي. إعادة تطبيق سياسة العزل وبشكل وأسع وخاصة بحق العق الأسرى القدامى. 
من أجل تحقيق أهداف الدر اسة قام الباحثان باستخدام المنهج الوصفي التحليلي الذي يحاو لا

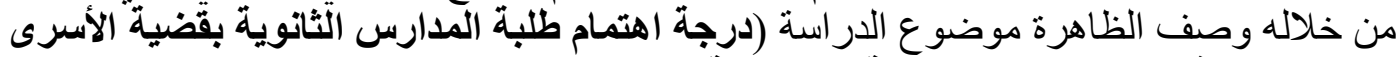

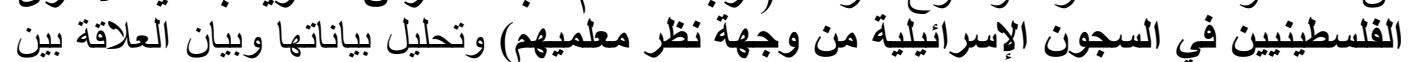

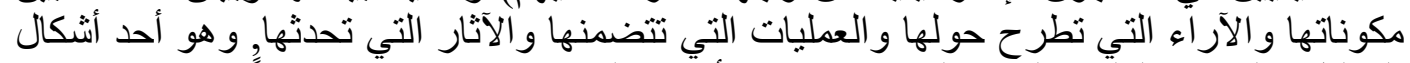

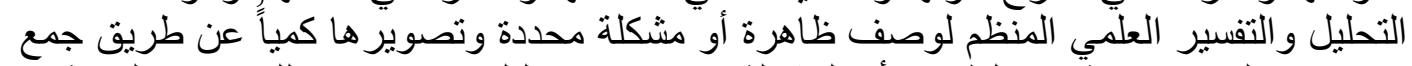

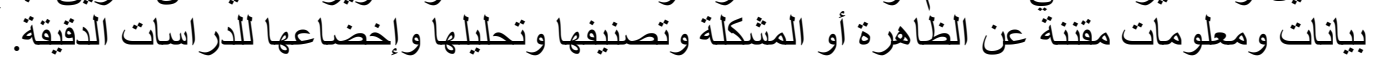

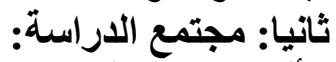
يتألف مجتمع الدر استة من جميع معلمي المرحلة الثانوية بمحافظات غزة للعام الدراسي (10 • بـ (r. $(17$

ثالثا: عينة الدار ماسة

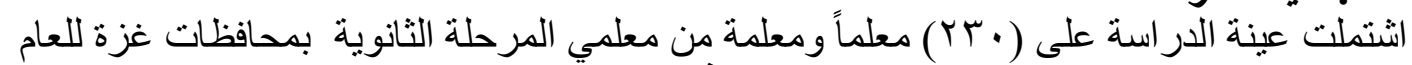

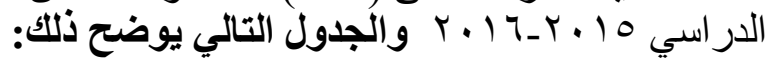

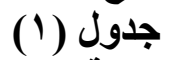

يبين أفراد عينة الدراسة حسب متغيرات الدراسة

\begin{tabular}{|c|c|c|c|}
\hline المئوية & العدد & & المتغير ات \\
\hline 57.83 & 133 & ذكر & \multirow{2}{*}{ النوع } \\
\hline 42.17 & 97 & أنثى & \\
\hline 8.26 & 19 & خمس سنو ات فما دون & \multirow{3}{*}{ الخدمة } \\
\hline 35.22 & 81 & من 0ــ ا سنو ات & \\
\hline 56.52 & 130 & أكثر من · ا سنوات & \\
\hline 42.17 & 97 & خان يونس & \multirow{2}{*}{ التعليمية } \\
\hline 57.83 & 133 & شرق خان يونس & \\
\hline 82.61 & 190 & بكالوريوس & \multirow{2}{*}{ العلمئ هل } \\
\hline 17.39 & 40 & در اسات عليا & \\
\hline 100 & 230 & المجموع & \\
\hline
\end{tabular}

أداة الدراسة : أدان أعد الباحثان أداة لمعرفة درجة الهنة الثمام طلبة المدارس الثانوية بقضية الأسرى القلسطينيين في

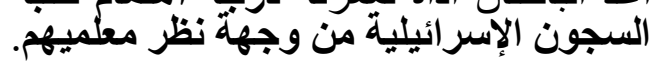

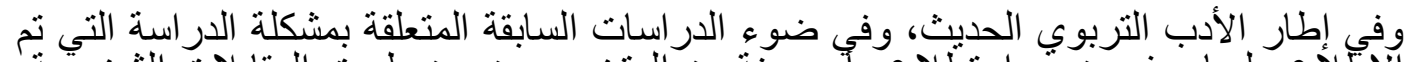

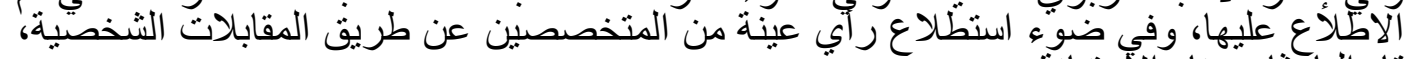
قام الباحثنان ببناء الآستبانة.

صدق الاستبانة: البن ويقصد بصدق الاستبانة: أن تقيس فقرات الاستبانة ما وضعت لقياسه وقام الباحثان بالتأكد من

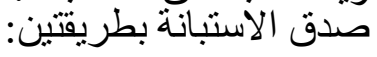

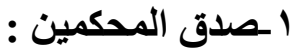

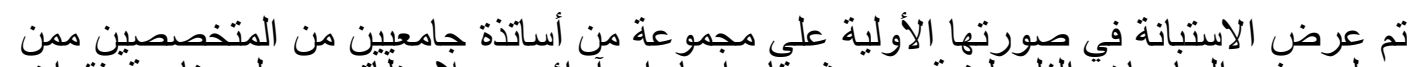

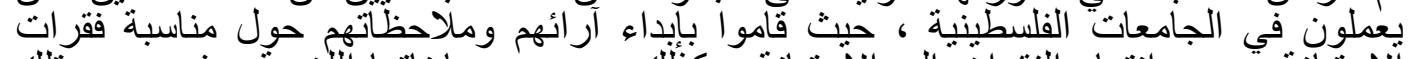

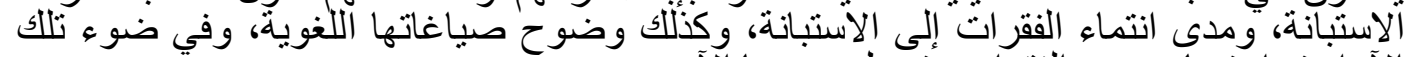

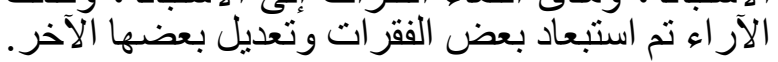




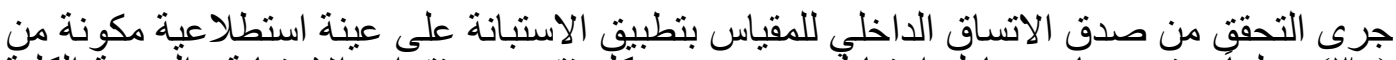

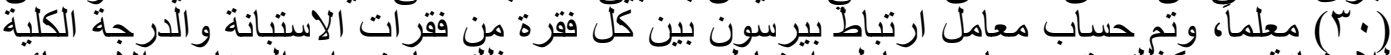

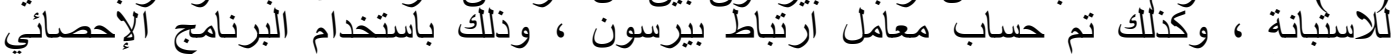

(SPSS)

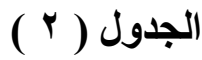

معامل ارتباط كل فقرة من فقرات الاستبانة مع الارجة الكلية للاستبانة

\begin{tabular}{|c|c|c|c|c|c|c|c|c|c|c|c|}
\hline الارتباط & 5 & |البعد & |الارتباط & e & |البعد & الارتباط & ? & البعد & الارتباط & & |لبعد م \\
\hline ***0.634 & 1 & $E^{*}:$ & $* * 0.67$ & 1 & \{ & $* * 0.871$ & 1 & $E^{*}$ & $* * 0.882$ & 1 & \\
\hline$* * 0.841$ & 2 & bi: & (**0.84 & 2 & $E$ & $* * 0.859$ & 2 & & $* * 0.775$ & $r$ & \\
\hline$* * 0.877$ & 3 & $\underline{E}$ & $8 * 0.83$ & 3 & & $* * 0.712$ & 3 & $\frac{e_{2}}{6}$ & $* * 0.549$ & $r$ & $\frac{c}{b_{i}^{2}}$ \\
\hline$* * 0.769$ & 4 & $\xi^{E}$ & $\begin{array}{l}* * 0.71 \\
8\end{array}$ & 4 & E & $* * 0.813$ & 4 & 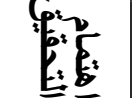 & $* * 0.747$ & $\varepsilon$ & $E$ \\
\hline **0.791 & 5 & E: & & & & & & & $* * 0.813$ & 5 & 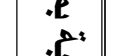 \\
\hline$* * 0.693$ & 6 & $k_{\infty}$ & & & & & & & $* * 0.618$ & 6 & \\
\hline$* * 0.598$ & 7 & $E$ & & & & & & & $* * 0.589$ & 7 & Б \\
\hline
\end{tabular}

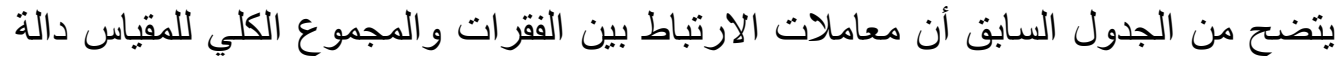

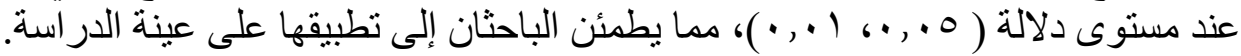

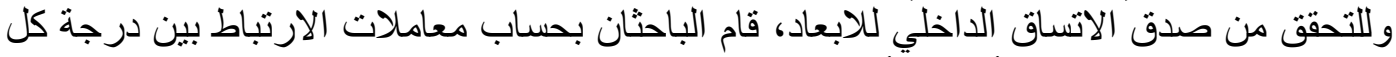

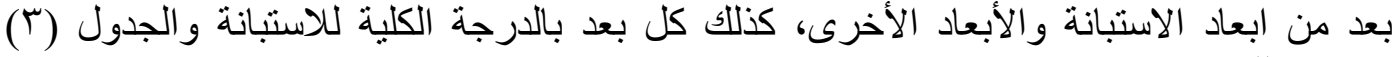

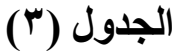

يوضح نللك.

مصفوفة معاملات ارتباط كل بعد من ابعاد الاستبانة والابعاد الأخرى للاستبانة وكذلك مع الارجة الكلية

\begin{tabular}{|c|c|c|c|c|}
\hline المترحامة الحكمة & التمقيفة الطبلة & والاتهام التمام التحقيق & الاعرحمة الطقة & \\
\hline & & 1 & 0.869 & الاعتمام الطلبة بمرحلة \\
\hline & 1 & 0.799 & 0.947 & التحقيق الطاتبة بمرحلة \\
\hline 1 & 0.703 & 0.651 & 0.812 & توقيف المعتقلة بمرحلة \\
\hline 0.576 & 0.805 & 0.548 & 0.854 & المكمام وقضاءة الطلبة بمرحلة فترة \\
\hline
\end{tabular}




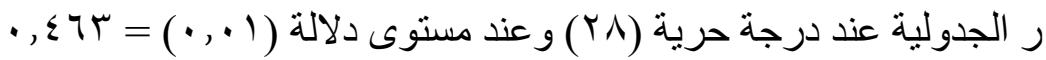

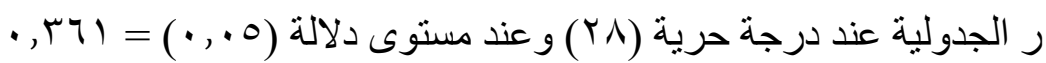

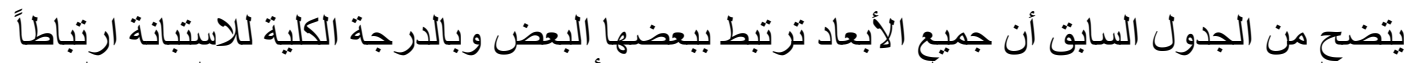

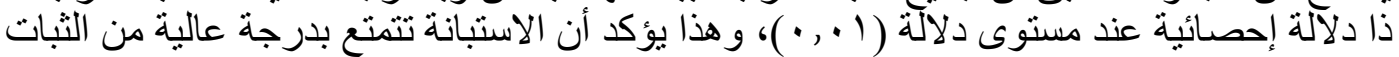
و الاتساق الداخلي.

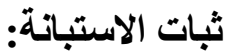

تم تقدير ثبات الاستبانة على أفر اد العينة الاستطلاعية وذلك باستخدام طريقتي معامل ألفا كرونباخ

تم استخدام درجات العينة الاستطلاعية لحساب ثبات الاستبانة بطريقة التجزئة النصفية، حيث قام الباحث بتجزئة الاستبانة إلى نصفين، الفقرات الفردية مقابل الفقرات الزوجية لكل مجال من مجالات الاستبانة، وذلك بحساب معامل الارتباط بين النصفين، ثم جرى تعديل الطول باستخدام

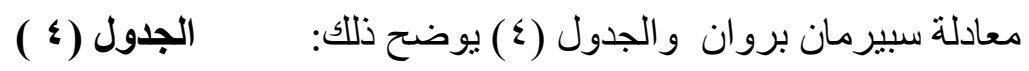

يوضح معاملات الارتباط بين نصفي كل مجال من مجالات الاستبانة وكذلك الاستبانة ككل قبل

\begin{tabular}{|c|c|c|c|}
\hline | معامل الثبات بعد | & التعديّيط قبل & عدد الفقرات & المجال \\
\hline 0.735 & 0.717 & $V *$ & ا هتمام الطلبة بمرحلة الاعتقال (الاسر) \\
\hline 0.756 & 0.611 & 4 & اهتمام الطلبة بمرحلة التحقيق والاتهام \\
\hline 0.811 & 0.682 & 4 & اهتمام الطلبة بمرحلة توقيف المعتقل \\
\hline 0.810 & 0.745 & *7 & المحاكمة إلطبه بمرحله الحكم وفضاء فتره \\
\hline 0.873 & 0.776 & 22 & الارجة الكلية \\
\hline
\end{tabular}
التعديل ومعامل الثبات بعد التعديل بـاطيل

*تم استخدام معادلة جتمان لان النصفين غير متساويين

يتضح من الجدول السابق أن معامل الثبات الكلي (AVT, •)، وهذا يدل على أن الاستبانة تتمتع بدرجة عالية من الثبات تطمئن الباحثان إلى تطبيقها على عينة الدر اسة.

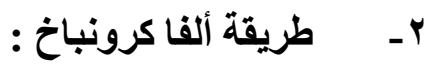

استخدم الباحثان طريقة أخرى من طرق حساب الثبات وهي طريقة ألفا كرونباخ، وذلك لإيجاد معامل ثبات الاستبانة، حيث حصل على قيمة معامل ألفا لكل مجال من مجالات الاستبانة، وكذلك للاستبانة ككل و الجدول (0 ) يوضح ذلك: 


\section{الجدول (• )}

يوضح معاملات ألفا كرونباخ لكل مجال من مجالات الاستبانة وكذلك للاستبانة ككل

\begin{tabular}{|c|c|c|}
\hline معامل ألفا كرونباخ & عدد الفقرات & المجال \\
\hline 0.840 & V & اهتمام الطلبة بمرحلة الاعتقال (الأسر) \\
\hline 0.831 & 4 & ا هتمام الطلبة بمرحلة التحقيق والاتهام \\
\hline 0.773 & 4 & اهتمام الطلبة بمرحلة توقيف المعتقل \\
\hline 0.867 & 7 & اهتمام الطلبة بمرحلة الحكم وقضاء قُترة المحاكمة \\
\hline 0.936 & 22 & الدرجة الكلية \\
\hline
\end{tabular}

يتضح من الجدول السابق أن معامل الثبات الكلي (דسو , •)، وهذا يدل على أن الاستبانة تتمتع بدرجة عالية من الثبات تطمئن الباحث إلى تطبيقها على عينة الدر اسة، ويعني ذلك أن هذه الأداة لو أعيد تطبيقها على أفراد الدراسة أنفسهم أكثر من مرة لكانت النتائج مطابقة بشكل كامل تقريباً ويطلق على نتائجها بأنها ثابتة.

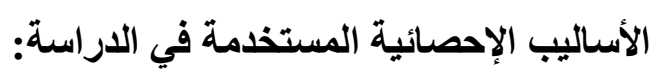

لقد قام الباحثان بتفريغ وتحليل الاستبانة من خلال برنامج (SPSS) الإحصائي وتم استخدام الأساليب الإحصائية التالية:

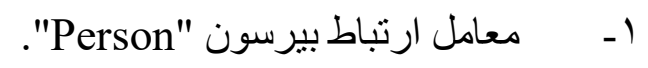

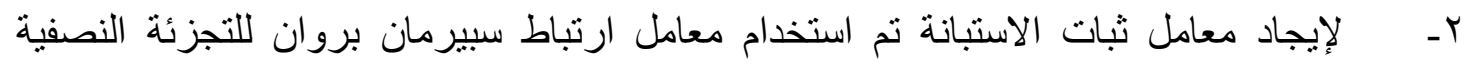
المتساوية، ومعادلة جتمان للتجزئة النصفية غير المتساوية، ومعامل ارتباط ألفان الفا كرونباخ.

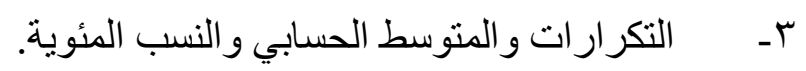

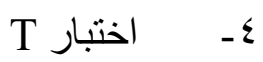

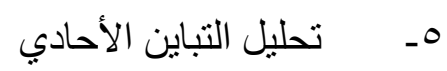

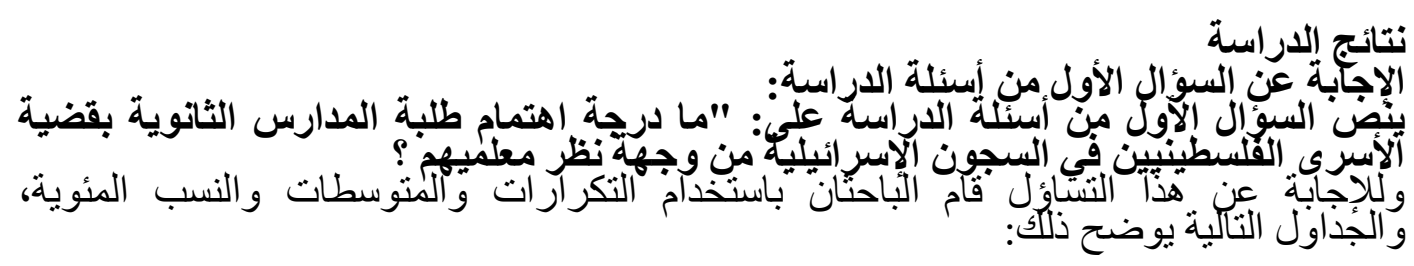
المجال الأول: اهتمام الطلبة بمرحلة الاعتقال (الأسر) 


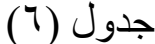

التكر ار ات والمتوسطات والانحر افات المعيارية والوزن النسبي لكل فقرة من فقرات المجال الأول

وكذلك ترتيبها

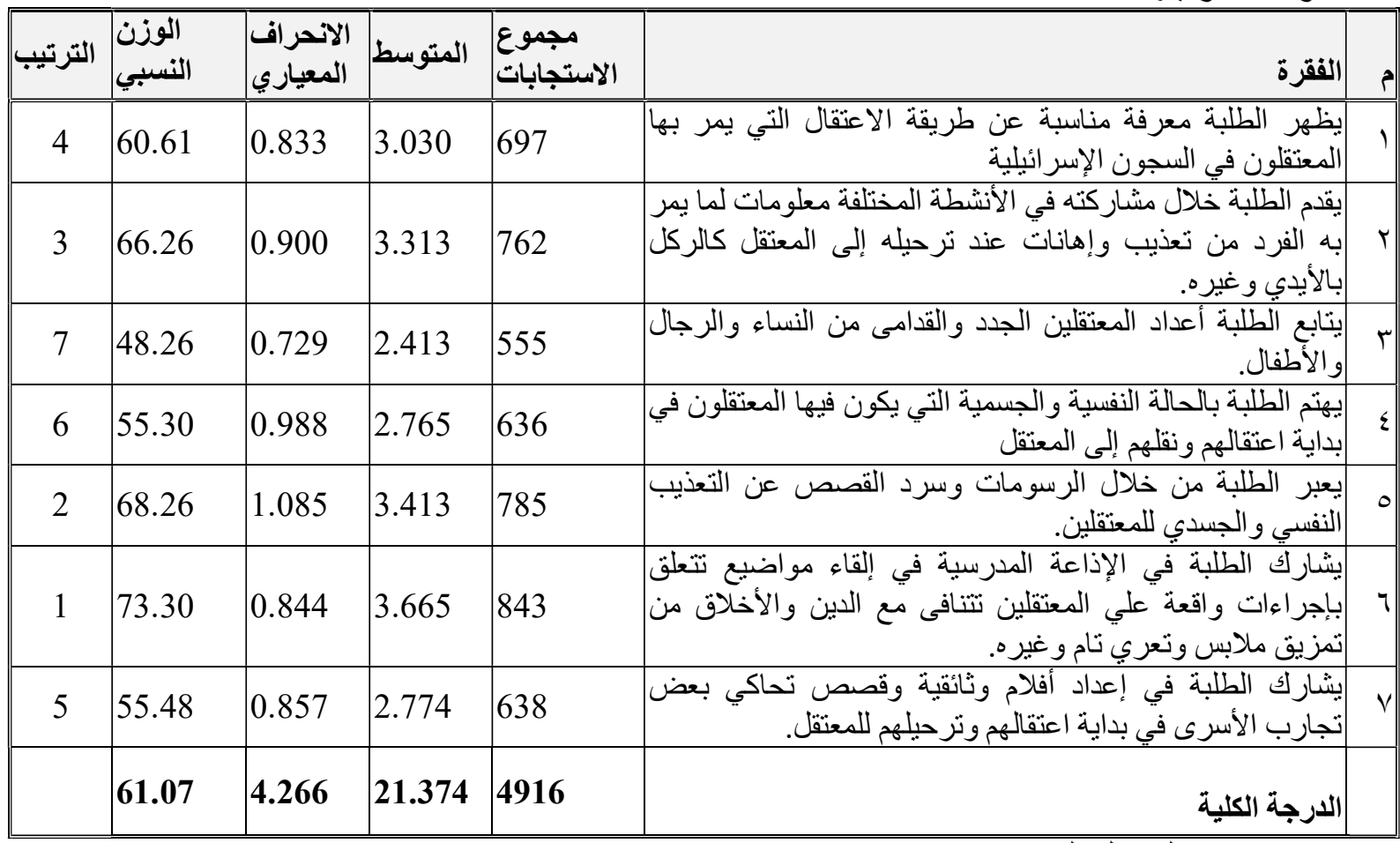

بتضخح من الجدول السابق: أن أعلى فقرتين في المجال كاتت:

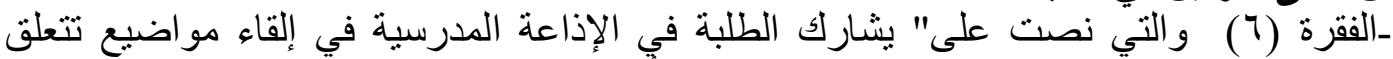

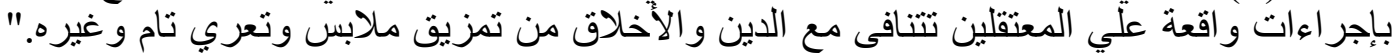

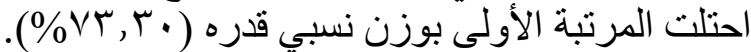

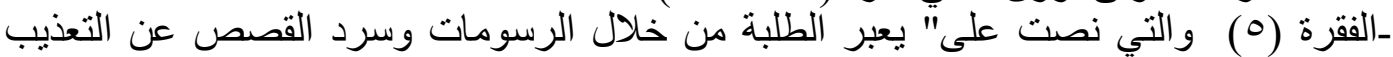

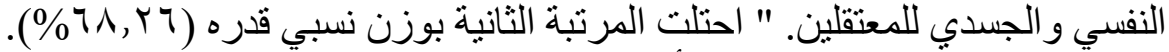

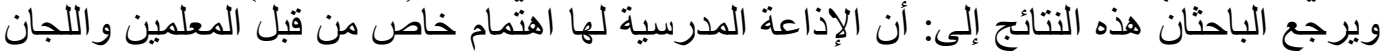

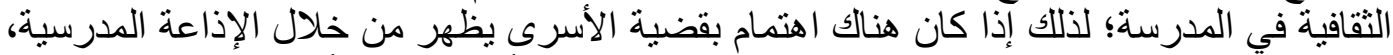

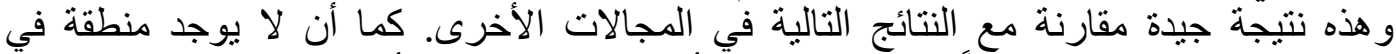

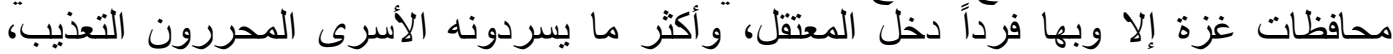
و أثنكاله؛ لذلك يبرز الطلبة ميو لاتهم وتفكير هم أثناء الرسومات التهات. وأن أدنى فقرتين في المجال كاتث:

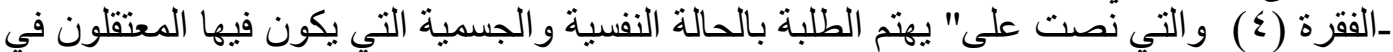

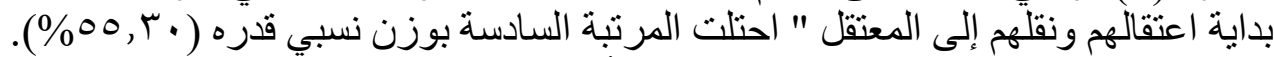

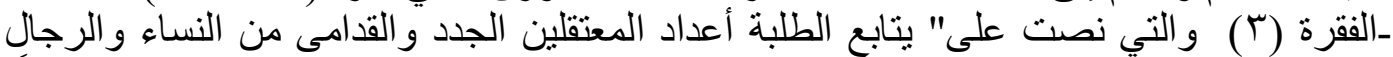

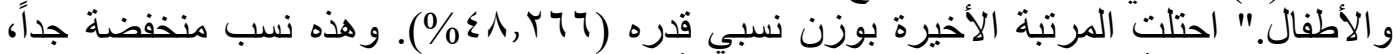

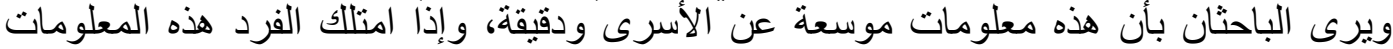

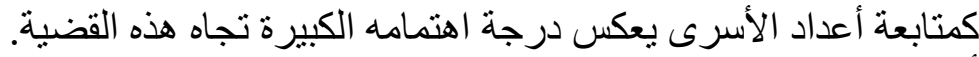

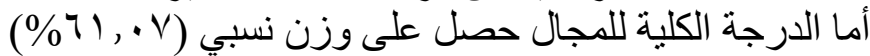
ويرى الباحثان بأن الدرجة الكلية للمجال غير مرضية المية ولان تليق بأهمية قضية الأسرى في المجتمع

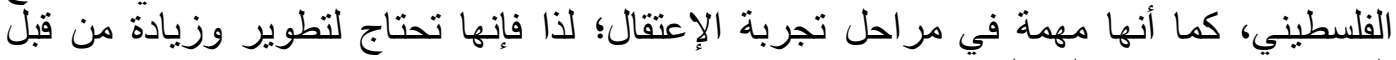
المتخصصين في هذا المجال. 


\section{المجال الثاني ا هتمام الطلبة بمرحلة التحقيق والاتهام}

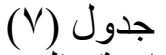

التكر ار ات و المتوسطات و الانحر افات المعيارية و الوزن النسبي لكل فقرة من فقرات المجال الثاني

وكذللك ترتيبها

\begin{tabular}{|c|c|c|c|c|c|c|}
\hline |الترتيب & |النسبني & الالمعرافي & المتوسط & | الاستجوعات إبات & |الفقرة & \\
\hline 2 & 65.57 & 1.041 & 3.278 & 754 & 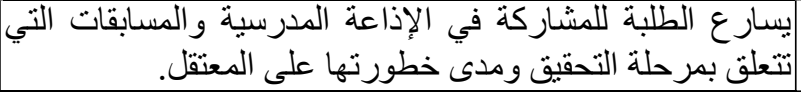 & \\
\hline 1 & 66.43 & 0.887 & 3.322 & 764 & 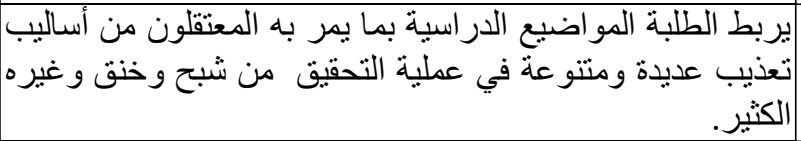 & Y \\
\hline 4 & 62.17 & 0.842 & 3.109 & 715 & 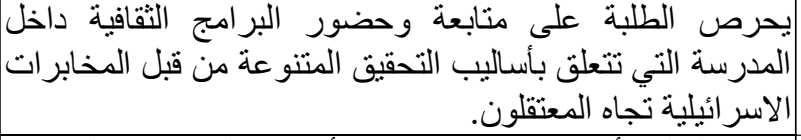 & $r$ \\
\hline 3 & 64.52 & 0.852 & 3.226 & 742 & 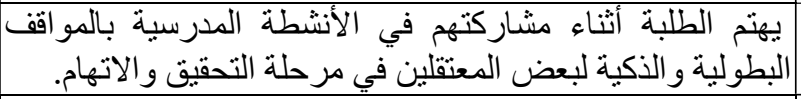 & $\varepsilon$ \\
\hline & 64.67 & 2.991 & 12.935 & 2975 & الارجة الكلية & \\
\hline
\end{tabular}

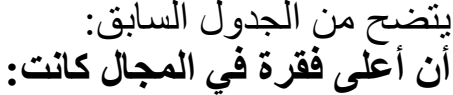

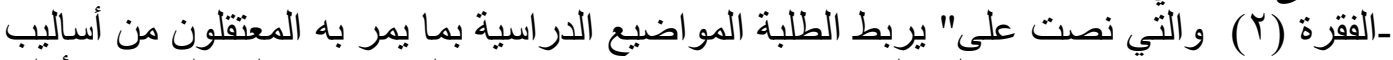

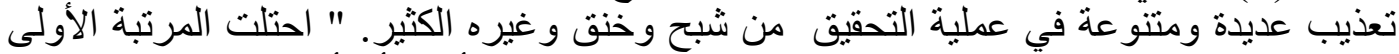

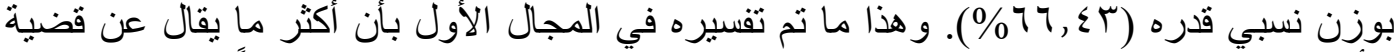

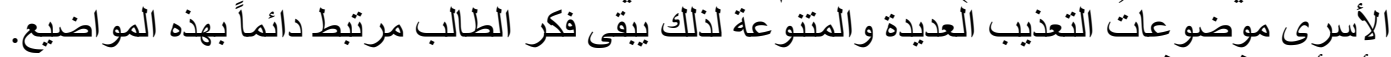

وأن أدنى فقرة في المجال كانت:

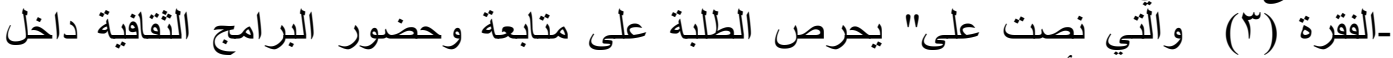

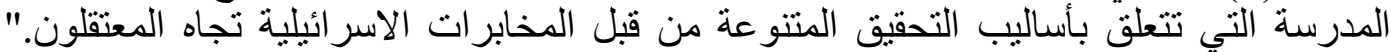

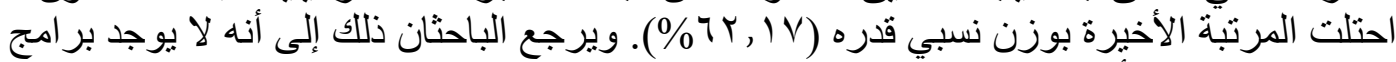

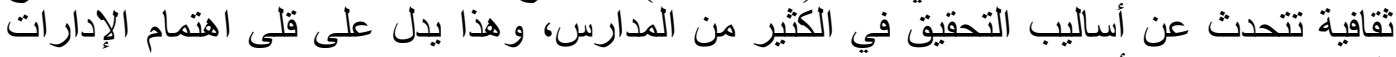
المدرسية بقضية الأسرى. تأسن.

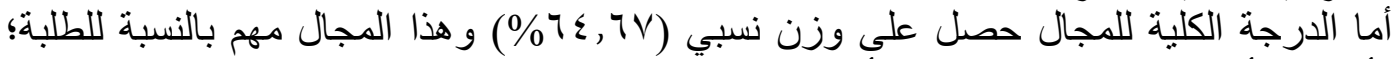

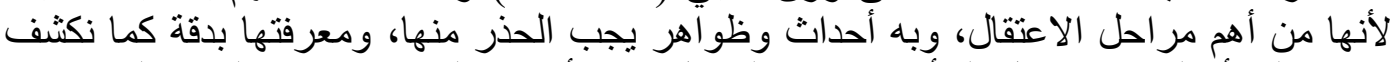

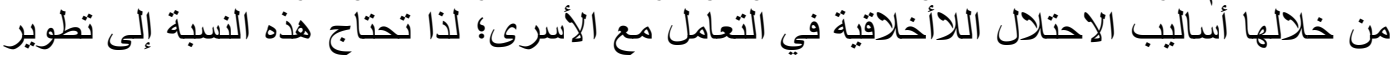
وزيادة من قبل العاملين في الميدان التربوي. 
or.

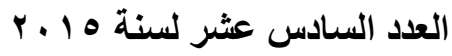
مجلة البحث العلمى فى التربية

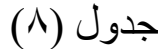

التكر ار ات والمتوسطات و الانحر افات المعبارية والوزن النسبي لكل فقرة من فقرات المجال الثالث

وكذللك ترنيبها

\begin{tabular}{|c|c|c|c|c|c|}
\hline الترتيب & 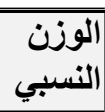 & 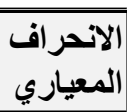 & المتوسط & 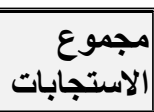 & |الفقرة \\
\hline 3 & 60.35 & 0.851 & 3.017 & 694 & 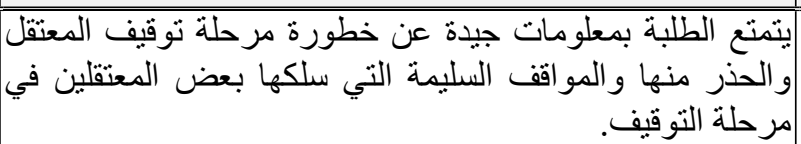 \\
\hline 1 & 66.17 & 0.918 & 3.309 & 761 & 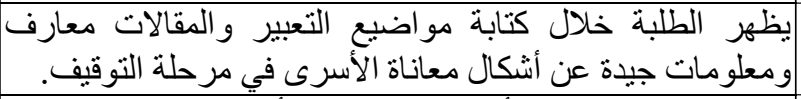 \\
\hline 2 & 63.83 & 0.866 & 3.191 & 734 & 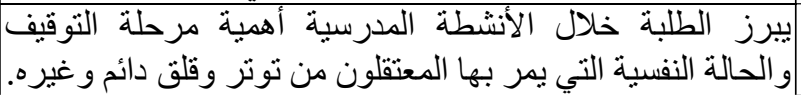 \\
\hline 4 & 57.13 & 0.892 & 2.857 & 657 & | يمتلك الطلبة معلومات ومعارف هافير في عن دور أفراد المخابرات \\
\hline & 61.87 & 2.813 & 12.374 & 2846 & \\
\hline
\end{tabular}

يتضح من الجدول السابق:

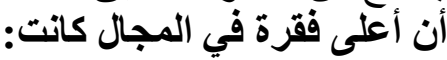

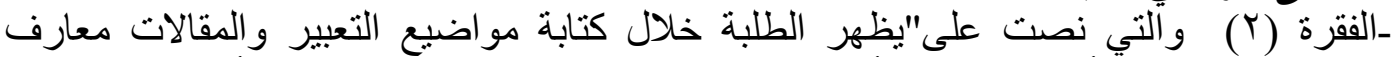

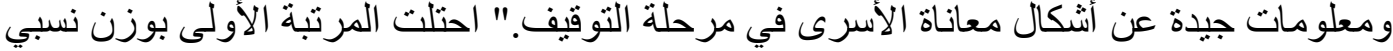

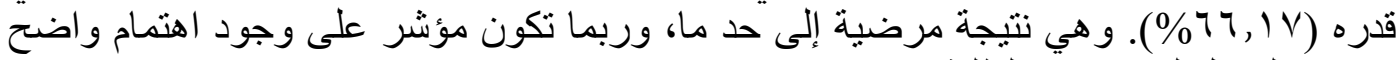

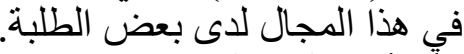

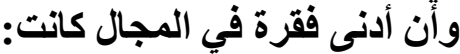
ـالفقرة (ع) و التي نصت على" يمتلك الطلبة معلومات ومعارف هامة عن دور أفر اد المخابرات

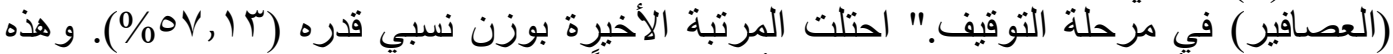
نتيجة مؤسفة لأن هذه المعلومات في غاية الأهمية خاصةً دور العصافيرة العير في مرحلة التوقيف وكثير

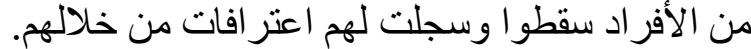

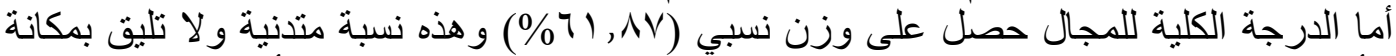
الأسرى الفلسطينيين في السجون الاسر ائيلية و لا بالتضحيات التي يقدمونها من أجل فلسطين و إنهاء قضيتها.

المجال الرابع اهتمام الطلبة بمرحلة الحكم وقضاء فترة المحاكمة

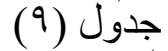

التكرار ات والمتوسطات و الانحر افات المعيارية والوزن النسبي لكل فقرة من فقرات المجال الرابع

\begin{tabular}{|c|c|c|c|c|c|c|}
\hline الترتيب & النسنب & الانـحراف & المتوسط & الاستجوعابات & |لفقرة & \\
\hline 7 & 56.61 & 0.868 & 2.830 & 651 & 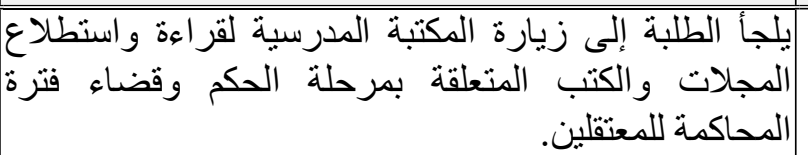 & 1 \\
\hline 6 & 58.17 & 1.017 & 2.909 & 669 & 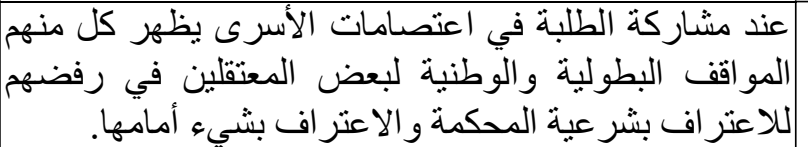 & $T$ \\
\hline 5 & 60.78 & 0.973 & 3.039 & 699 & 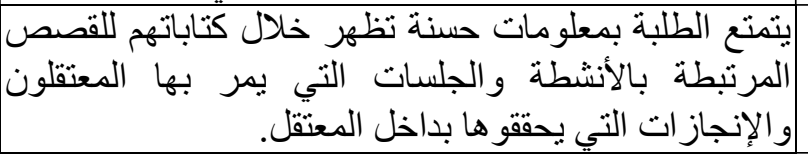 & r \\
\hline
\end{tabular}




\begin{tabular}{|c|c|c|c|c|c|c|}
\hline |الترتيب & النوزن & |الانحراف & المتوسط & | - الاستجوعابات & | الفقرة & \\
\hline 1 & 64.96 & 0.833 & 3.248 & 747 & 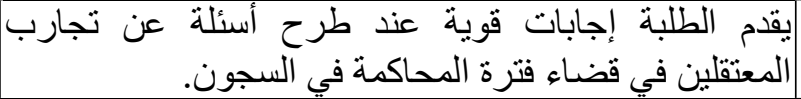 & \\
\hline 2 & 64.87 & 0.788 & 3.243 & 746 & 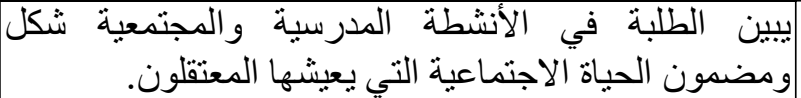 & 0 \\
\hline 4 & 61.04 & 0.855 & 3.052 & 702 & في السجد الطلبة تجارب الائية. متعددة ومتتوعة للمعتقلين الفلسطينيين & 7 \\
\hline 3 & 64.43 & 0.851 & 3.222 & 741 & 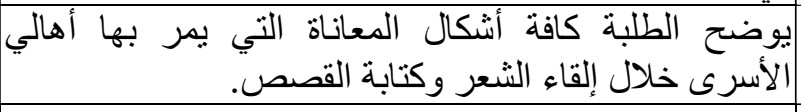 & $V$ \\
\hline & 61.55 & 4.877 & 21.543 & 4955 & الدرجة الكلية & \\
\hline
\end{tabular}

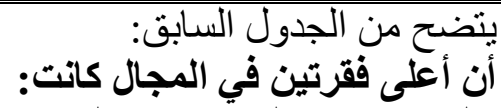

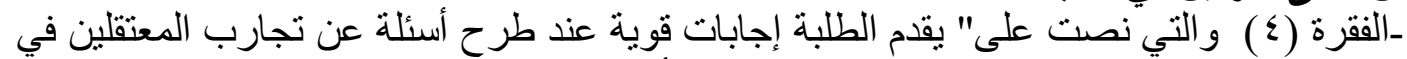

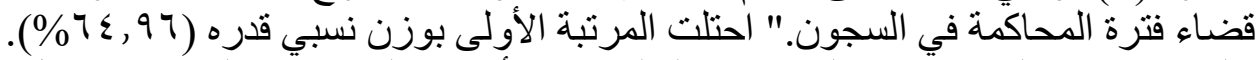

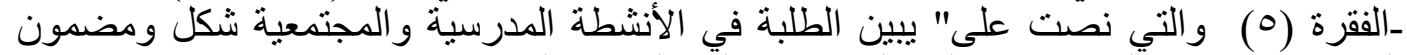

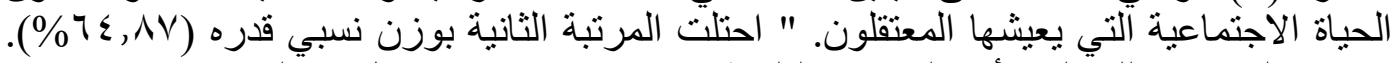

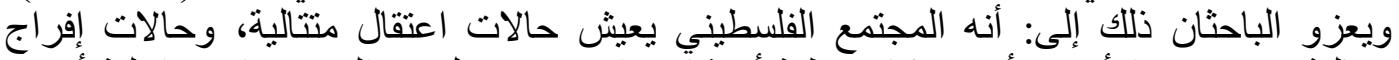

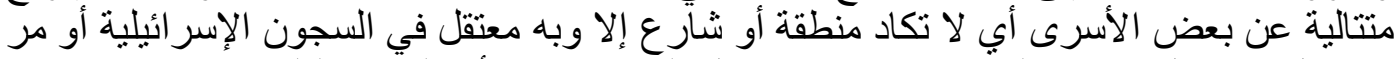

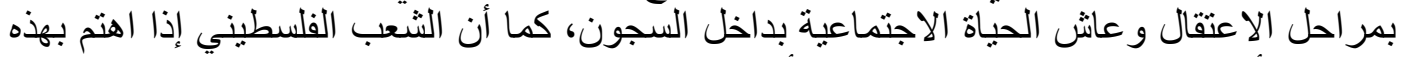

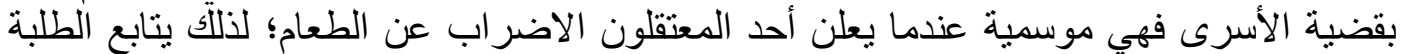

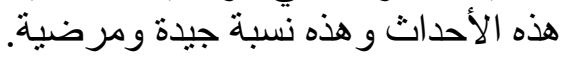

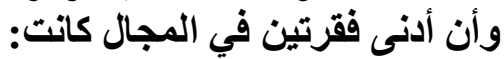

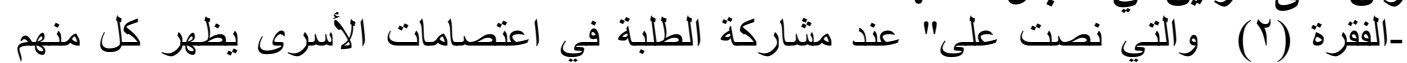

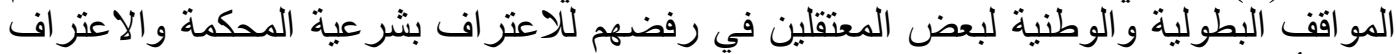

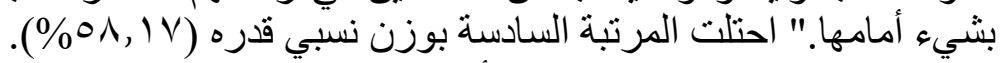

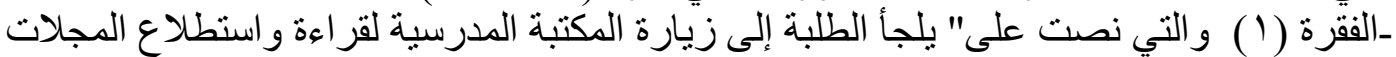

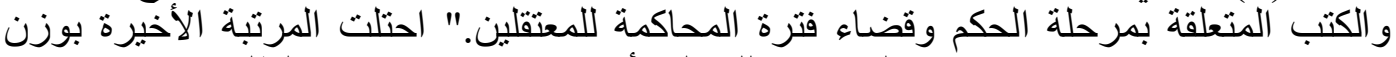

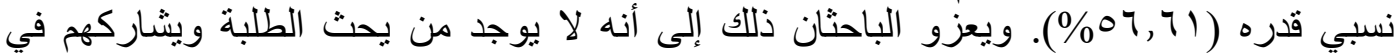

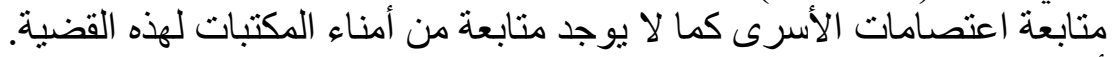

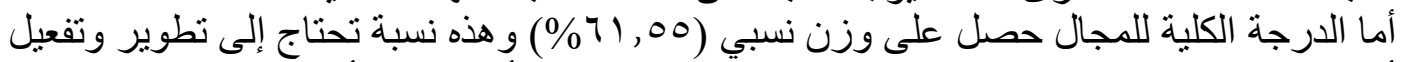

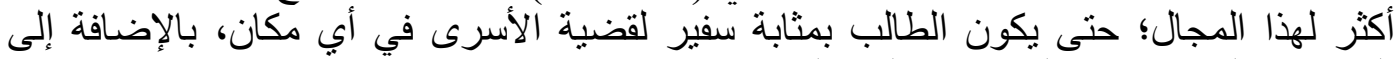

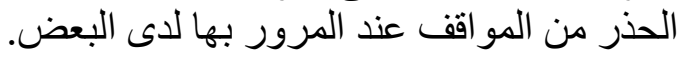

\section{الإجابة عن السؤال الثاني من أسئلة الدراسة:}

ينص السؤال الثاني على: هل توجد فروق ذاتي الات دلالة إحصائية بين متوسطات تقدير ات أفراد عينة

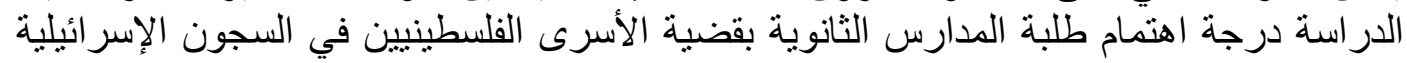

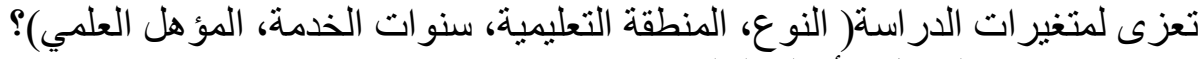
ويتفرع من هذا السؤ ال الأسئلة التالية:

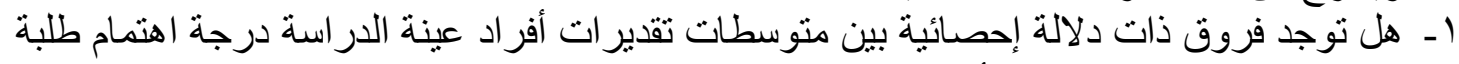

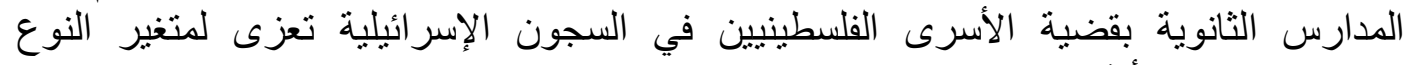
الاجتماعي(ذكر - أنثى) وللإجابة عن هذا السؤال قام الباحثان باستخدام اختبار "T. test" و الجدول ( • ( ) يوضح ذلك: 


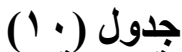

المتوسطات والاتحرافات المعيارية وقيمة "ت" للاستبانة تعزى لمتغير النوع

\begin{tabular}{|c|c|c|c|c|c|c|c|c|}
\hline الدالئةى & قيمة الدلالة & "قيمة" & الالمعرافي & المتوسط & العدد & & & \\
\hline \multirow{2}{*}{ | } & \multirow[t]{2}{*}{0.000} & \multirow[t]{2}{*}{4.630} & 4.812 & 20.308 & 133 & ذكر & \multirow{2}{*}{\multicolumn{2}{|c|}{ الاعتماّل (الأسلبة) بمرحلة }} \\
\hline & & & 2.801 & 22.835 & 97 & أنتى & & \\
\hline \multirow{2}{*}{ |دالة عند } & \multirow[t]{2}{*}{0.000} & \multirow[t]{2}{*}{3.684} & 3.388 & 12.331 & 133 & ذكر & \multirow[t]{2}{*}{ بمرحلة } & \\
\hline & & & 2.086 & 13.763 & 97 & أنثى & & \\
\hline \multirow{2}{*}{ 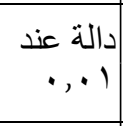 } & \multirow{2}{*}{0.001} & \multirow{2}{*}{3.487} & 3.063 & 11.835 & 133 & ذكر & \multirow[t]{2}{*}{ بمرحلة } & \multirow{2}{*}{ 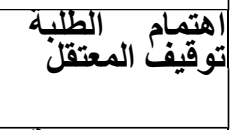 } \\
\hline & & & 2.240 & 13.113 & 97 & أنتى & & \\
\hline \multirow{2}{*}{ |إحصائياً } & \multirow[t]{2}{*}{0.657} & \multirow[t]{2}{*}{0.445} & 5.381 & 21.421 & 133 & ذكر & \multirow{2}{*}{ بمرحة } & \multirow{2}{*}{ وقضاء } \\
\hline & & & 4.108 & 21.711 & 97 & أنتى & & \\
\hline \multirow{2}{*}{ | } & \multirow[t]{2}{*}{0.001} & \multirow[t]{2}{*}{3.239} & 15.231 & 65.895 & 133 & ذكر & & \multirow{2}{*}{ الدرجة الكلية } \\
\hline & & & 8.315 & 71.423 & 97 & أنتى & & \\
\hline
\end{tabular}

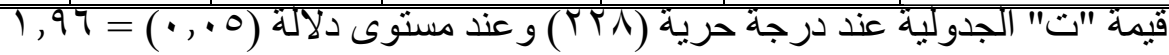

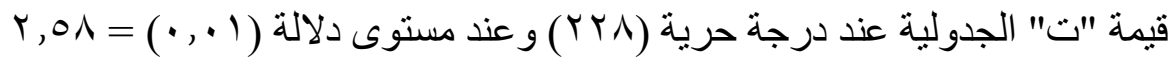

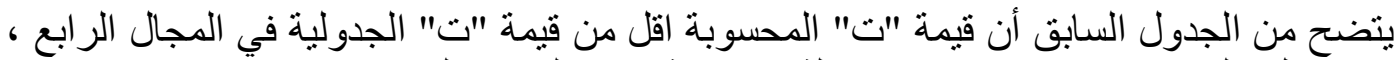

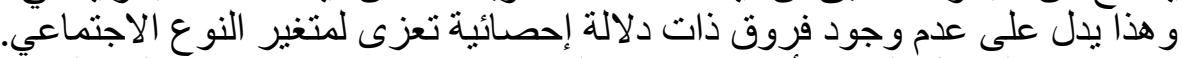

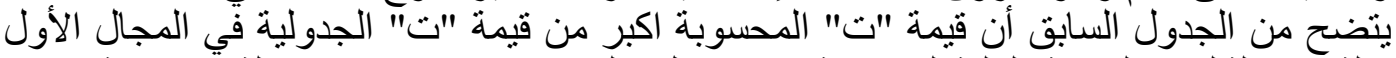

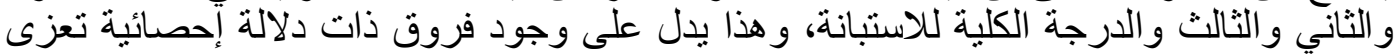

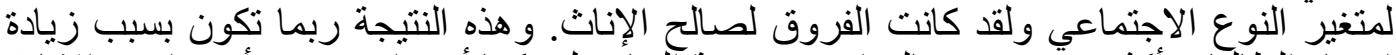

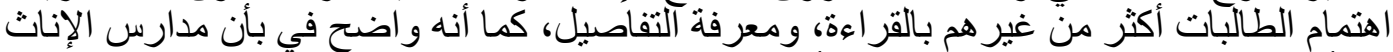

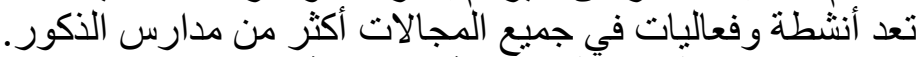

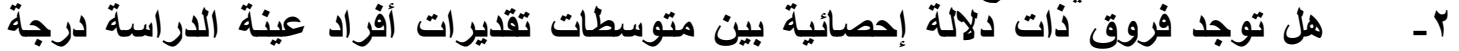

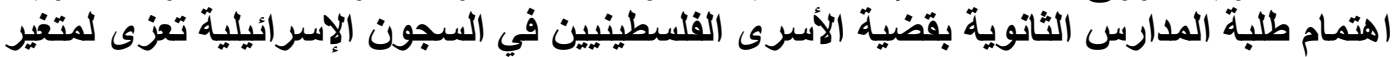

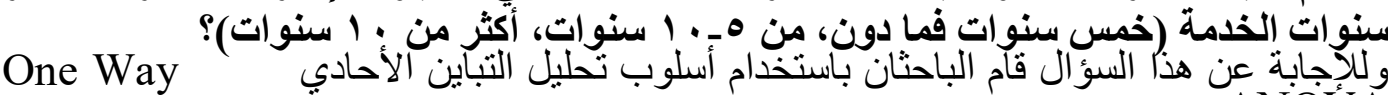
ANOVA جدول (1) (1) مصدر التباين ومجموع المربعات ودرجات الحرية ومتوسط المربعات وقيمة "ف" ومستوى الالالة تعزى لمتغير سنوات التوعين الخدمة

\begin{tabular}{|c|c|c|c|c|c|c|c|}
\hline الدلالية & |قالديمة & "قَفيم" & المربعات & الحرجية & مجموع المربعات | & |مصدر التباين & \\
\hline \multirow{3}{*}{ إحيردائياً } & \multirow{3}{*}{0.104} & \multirow{3}{*}{2.289} & 41.195 & 2 & 82.390 & |بين المجمو عات & \multirow{3}{*}{ 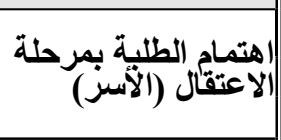 } \\
\hline & & & 17.998 & 227 & 4085.453 & داخل المجمو عات & \\
\hline & & & & 229 & 4167.843 & |المجموع & \\
\hline \multirow{3}{*}{ إحصائياً } & \multirow{3}{*}{0.864} & \multirow{3}{*}{0.147} & 1.320 & 2 & 2.641 & بين المجمو عات & \multirow{3}{*}{ |التحقيق والاتهام بمرحلة } \\
\hline & & & 9.010 & 227 & 2045.381 & داخل المجمو عات & \\
\hline & & & & 229 & 2048.022 & |المجموع & \\
\hline \multirow{3}{*}{ غيردالةًاً } & \multirow{3}{*}{0.855} & \multirow{3}{*}{0.157} & 1.250 & 2 & 2.500 & |بين المجمو عات & \multirow{3}{*}{ |توقيفِ المعثقبة بمرحلة } \\
\hline & & & \begin{tabular}{|l|}
7.971 \\
\end{tabular} & 227 & 1809.344 & داخل المجمو عات & \\
\hline & & & & 229 & 1811.843 & المجموع & \\
\hline \multirow{3}{*}{ إحيردائياً } & \multirow{3}{*}{0.549} & \multirow{3}{*}{0.601} & 14.342 & 2 & 28.683 & ابين المجمو عات & \multirow{3}{*}{ 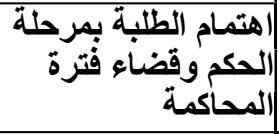 } \\
\hline & & & 23.870 & 227 & 5418.382 & داخل المجمو عات & \\
\hline & & & & 229 & 5447.065 & |المجموع & \\
\hline
\end{tabular}




\begin{tabular}{|c|c|c|c|c|c|c|c|c|}
\hline & مستولة & اقليملة & "فيمة" & المربعات & |الحرجية & مجموع المربعات | & |مصدر التباين & |البعد \\
\hline \multirow{3}{*}{ |دالة| } & \multirow{3}{*}{ إحير بئياً } & \multirow{3}{*}{0.647} & \multirow{3}{*}{0.436} & 74.642 & 2 & 149.284 & |بين المجمو عات & \multirow{3}{*}{ |الدرجة الكلية } \\
\hline & & & & \begin{tabular}{|l|}
171.026 \\
\end{tabular} & 227 & 38822.959 & داخل المجمو عات & \\
\hline & & & & & 229 & 38972.243 & |المجموع & \\
\hline
\end{tabular}

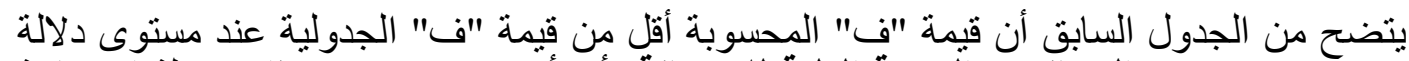

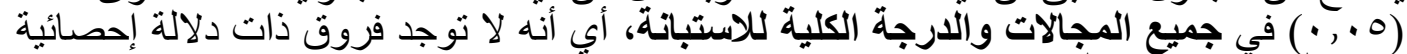
تعزى لمتغير سنوات الخدمة

ويرى الباحثان بأنه قد يرجع ذللك إلى أن جميع المعلمين بتطلعون على أداء الطلبة، ويلاحظون

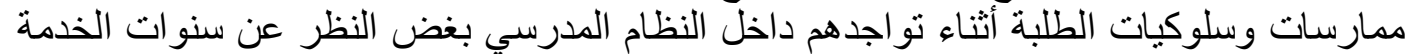
التي أمضوها. كما أن جميع المعلمين يخضعون للنشاطات نفسها التي تنظمها المدرسة في إطار

r- - هل توجد فروق ذات دلالة إحصائية بين متوسطات تقديرات أفراد عينة الدراسة درجة

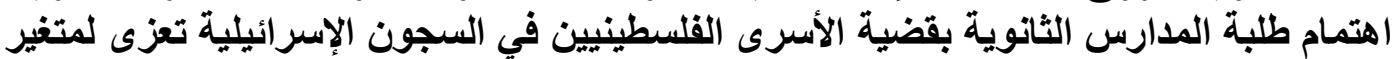

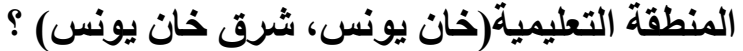
وللإجابة عن هذا السؤال قام الباحثان باستخدام اختبار "T. "T. test" و الجدول (r ( ) يوضح ذللك:

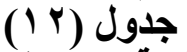

المتوسطات والاتحر افات المعيارية وقيمة "ت" للاستبانة تعزى لمتغير المنطقة التعليمية

\begin{tabular}{|c|c|c|c|c|c|c|c|}
\hline مستوى الدلالة & قيمة الدلالة & قيمة "ت" & الالانحراف & |المتوسط & | العدد & & \\
\hline \multirow{2}{*}{ غيردالة إحصائياً } & \multirow{2}{*}{0.612} & \multirow{2}{*}{0.508} & 3.786 & 21.206 & 97 & خان يونس & \multirow{2}{*}{ (الآسرّم) الطلبة بمرحلة الاعتقال } \\
\hline & & & 4.595 & 21.496 & 133 & 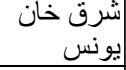 & \\
\hline \multirow{2}{*}{ غيردالة إحصائياً } & \multirow{2}{*}{0.076} & \multirow{2}{*}{1.780} & 3.079 & 12.526 & 97 & خان يونس & \multirow{2}{*}{ |والاتهام الطلبة بمرحلة التحقيق } \\
\hline & & & 2.900 & 13.233 & 133 & 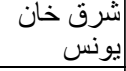 & \\
\hline \multirow{2}{*}{ دالةعند ا •, • } & \multirow{2}{*}{0.003} & \multirow{2}{*}{3.007} & 2.775 & 11.732 & 97 & خان يونس & \multirow{2}{*}{ الهعتملح الطلبة بمرحلة توقيف } \\
\hline & & & 2.757 & 12.842 & 133 & | & \\
\hline \multirow{2}{*}{ ـالة عند ا •., . } & \multirow{2}{*}{0.000} & \multirow{2}{*}{4.777} & 5.418 & 19.825 & 97 & |خان يونس & \multirow{2}{*}{ وقضاءع الطرةبة المحاكمة الحكم } \\
\hline & & & 4.020 & 22.797 & 133 & ايونس خان & \\
\hline \multirow{2}{*}{ دالة عند ا •, . } & \multirow{2}{*}{0.003} & \multirow{2}{*}{2.966} & 13.414 & 65.289 & 97 & خان يونس & \multirow{2}{*}{ اللارجة الكلية } \\
\hline & & & 12.386 & 70.368 & 133 & إيونس خان & \\
\hline
\end{tabular}

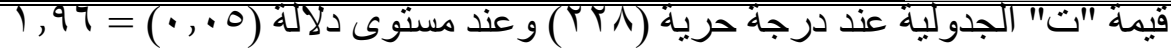

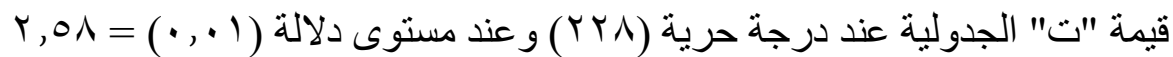
يتضح من الجدول السابق أن قيمة "ت" المحسوبة اقل من قيمة "ته

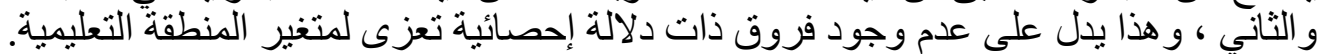

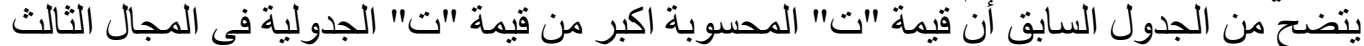

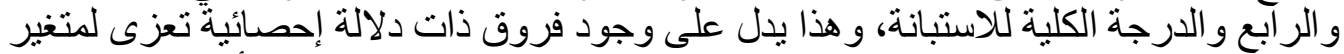

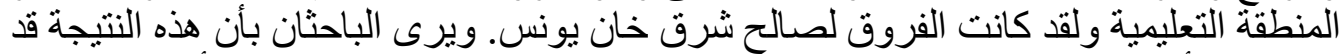

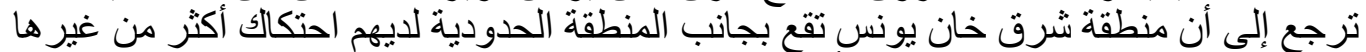
بالاحتلال وحالات الاعتقال قد تكون أكثر من غير هان في المنطة. 


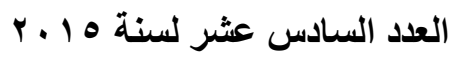

OrE

مجلة البحث العلمى فى التربية

عـ هل توجد فروق ذات دلالة إحصائية بين متوسطات تقديرات أفراد عينة الدراسة درجة اهتمام

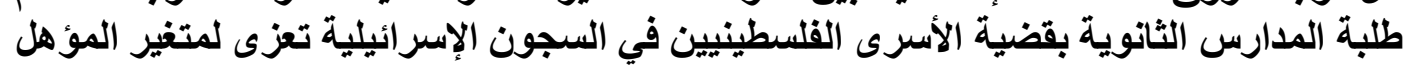

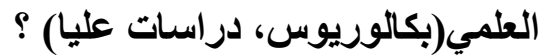
وللإجابة عن هذا السؤال قام الباحثًان باستخدام اختبار "T. test" و والجدول (ب ا ) يوضح ذلك:

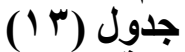

المتوسطات والانحر افات المعيارية وقيمة "تول لثلاستبانة تعزى لمتغير المؤهل العلمي

\begin{tabular}{|c|c|c|c|c|c|c|c|}
\hline |الدلالة & قيمة الدلالة & "تيمة" & |الانحر افياري & المتوسط & العدد & & \\
\hline \multirow{2}{*}{ مالة . • عند } & \multirow[t]{2}{*}{0.011} & \multirow[t]{2}{*}{2.560} & 4.353 & 21.047 & 190 & بكالوريوس & \multirow{2}{*}{ الاعتقامل الطلّة بمرحلة } \\
\hline & & & 3.474 & 22.925 & 40 & در اسات عليا & \\
\hline \multirow{2}{*}{ إعبر دائياً } & \multirow[t]{2}{*}{0.397} & \multirow[t]{2}{*}{0.849} & 3.108 & 12.858 & 190 & بكالوريوس & \multirow{2}{*}{ التحقيقي والطلبة بمرحلة } \\
\hline & & & 2.356 & 13.300 & 40 & در اسات عليا & \\
\hline \multirow{2}{*}{ دالة عند } & \multirow[t]{2}{*}{0.005} & \multirow[t]{2}{*}{2.828} & 2.928 & 12.137 & 190 & بكالوريوس & \multirow{2}{*}{ 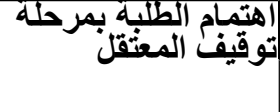 } \\
\hline & & & 1.826 & 13.500 & 40 & |در اسات عليا & \\
\hline \multirow{2}{*}{ إحصائياً } & \multirow[t]{2}{*}{0.085} & \multirow[t]{2}{*}{1.729} & 5.032 & 21.289 & 190 & بكالوريوس & \multirow{2}{*}{ 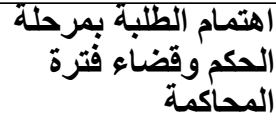 } \\
\hline & & & 3.894 & 22.750 & 40 & در اسات عليا & \\
\hline \multirow{2}{*}{ | } & \multirow[t]{2}{*}{0.023} & \multirow[t]{2}{*}{2.287} & 13.442 & 67.332 & 190 & بكالوريوس & \multirow{2}{*}{ الدرجة الكلية } \\
\hline & & & 10.059 & 72.475 & 40 & در اسات عليا & \\
\hline
\end{tabular}

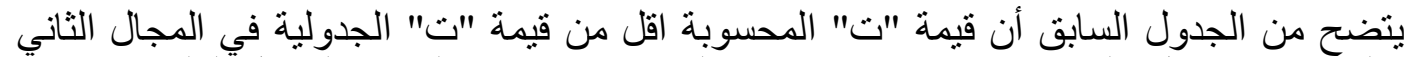

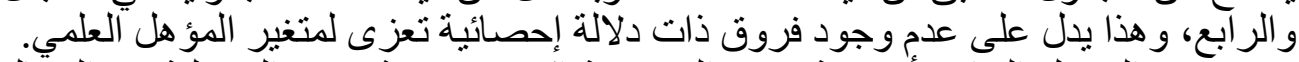

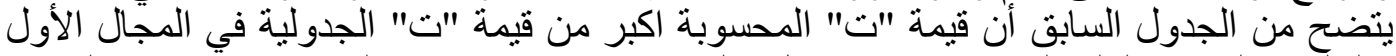

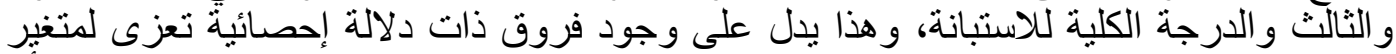

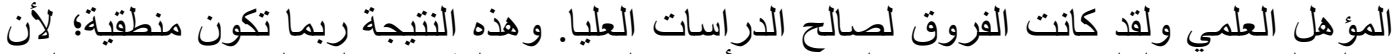

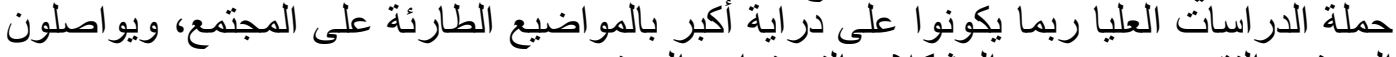

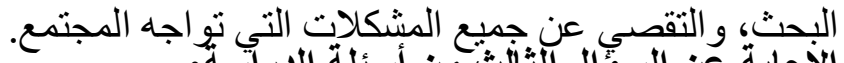

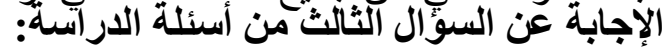
ماهي المقترحات التي يمكنها أن تزيد من درجة الهتمام طلبة المدارس الثانوية بقضية الأسرى الفلسطينينين

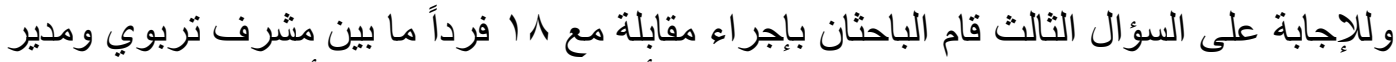

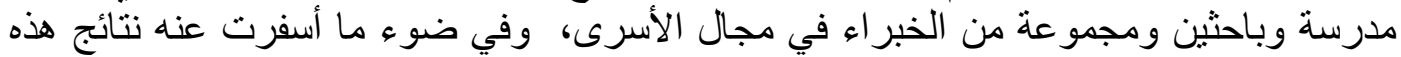

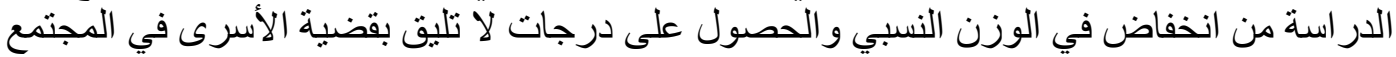

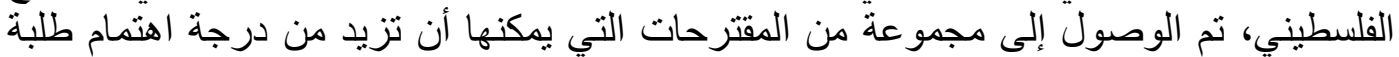

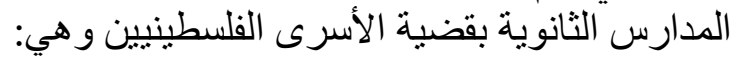

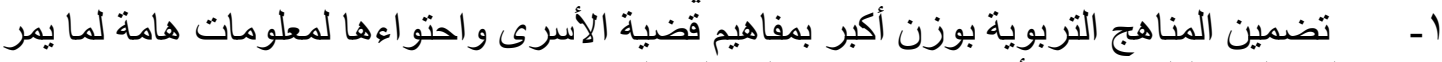

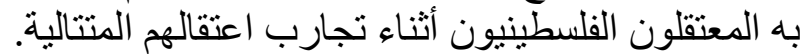
r - تقديم دور ات للمعلمين لزيادة معرفتهم بقضية الأسرى وحثهم للعمل على نشر الوعي بقضية

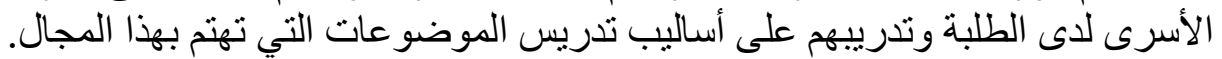

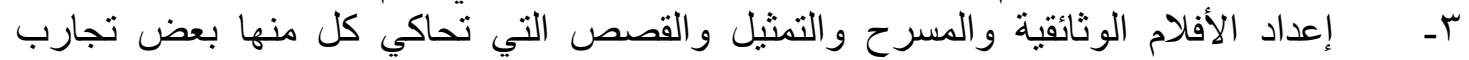
الاعتقال و عرضها على الطلبة. 


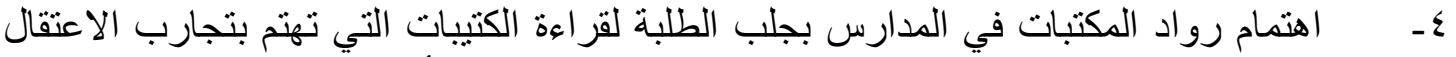
الفلسطينية في السجون الاسر ائيلية. وذلك من خلال إعداد مسابقات وأنشطة مكتبية في هذا المجات المال. 0ـ زيادة اهتمام وزارة التربية والتعليم العالي الفلسطينية بالمناسبات التي تخص قضية الأسرى

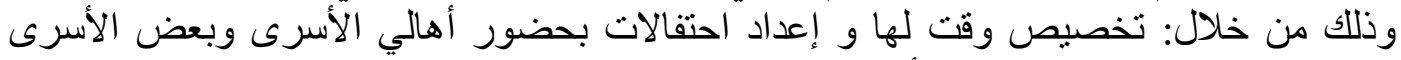

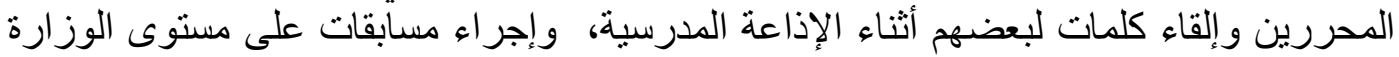
في جوانب تتعلق بقضية الاسرى. 7- - ي تفعيل الإذاعة المدرسية و الإنمام بدور ها في نشر القضية الفلسطينية والتي تعتبر من الثوابت الفلسطينية وهم الأسرى في السجة السجون.

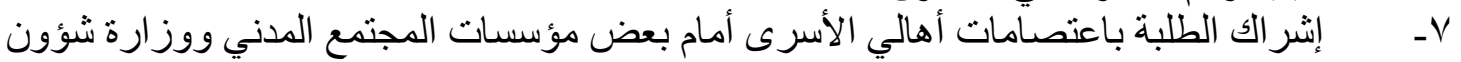

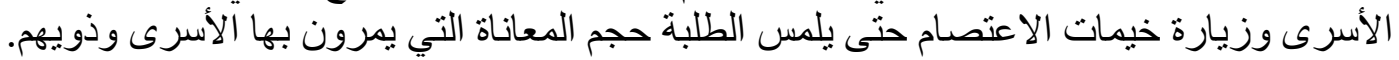

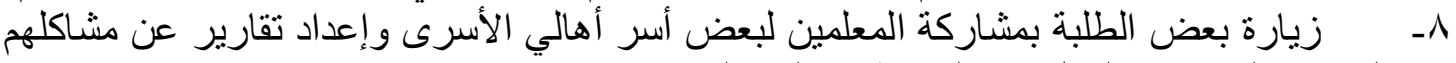
المادية و المعنوية و العمل قدر المستطاع على حلى حلها.

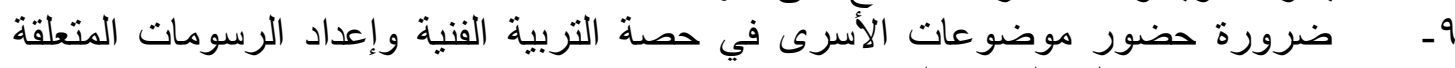
ببعض حالات الاعتقال كالثبح و التعذيب و وغيره توصيات الدراسة: في ضوء نتائج الدراسة اسة، يوصي الباحتثان بما يلي:

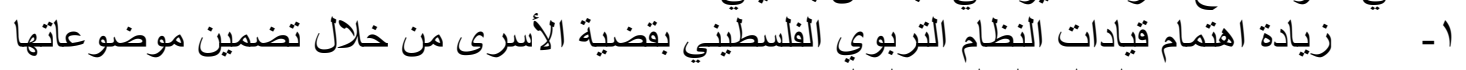
في جميع مدخلات العملية التعليمية التعلمية.

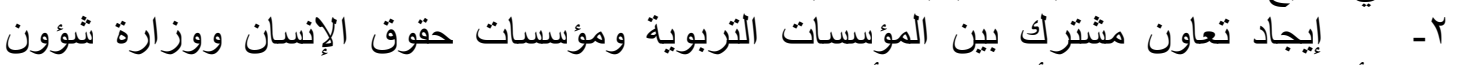

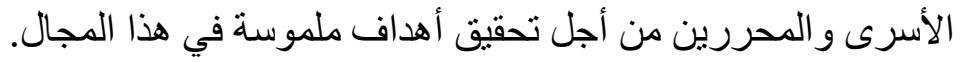

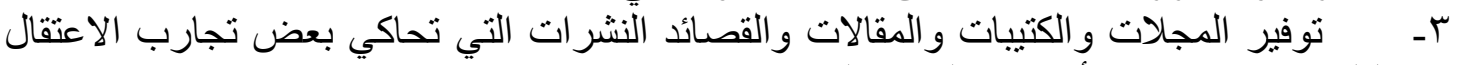

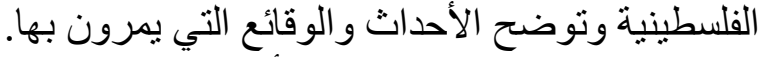

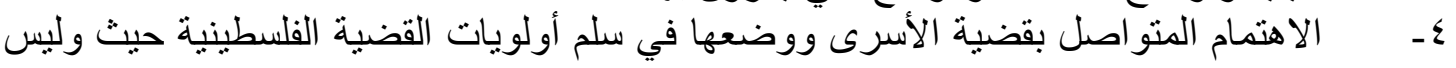
أن تثار فقط في زمن وظروف موسمية.

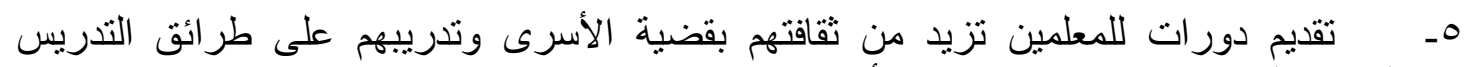
المناسبة لعرض موضو عات قضية الأسرى.

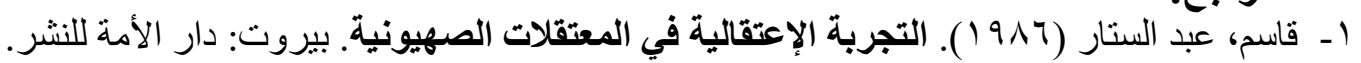

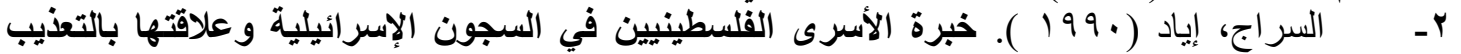

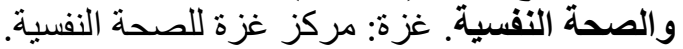

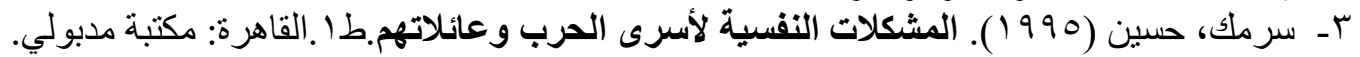

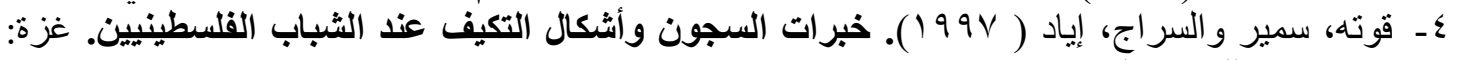

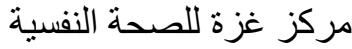
ــ أبو طواحينة، أحمد(999 (199). الأثار النفسية للتعذيب: دراسة امبريقية للمعتقلين السياسيين الذين تعرضوا و الذين لم يتعرضوا للتعذيب داخل السجون الاسرائيلية. رسالة دكتوراة غير منشورة. جامعة الأية عين شمس. القاهرة.

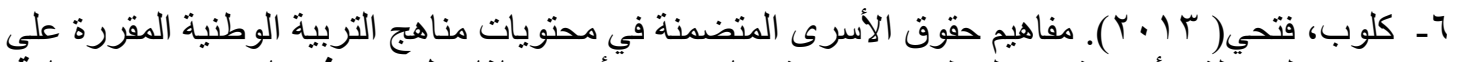

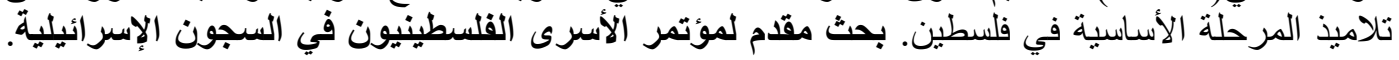

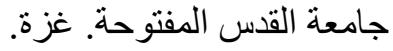

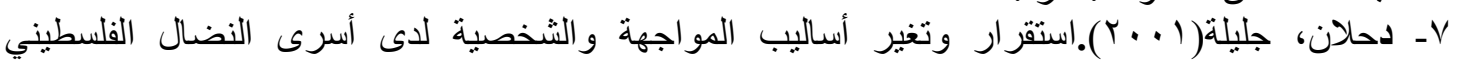

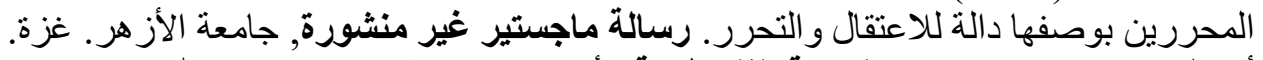

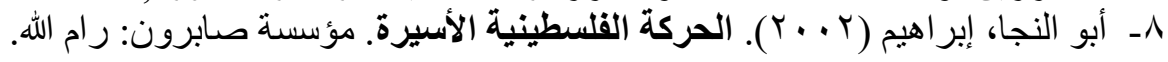




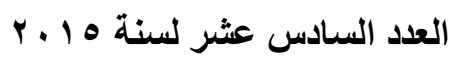

ory

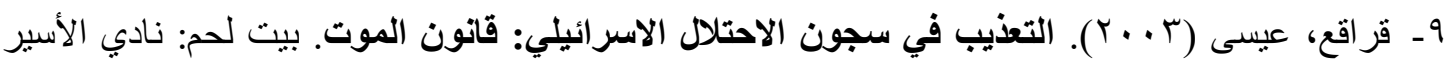
الفلسطيني.

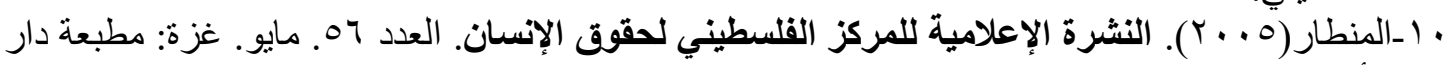

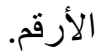

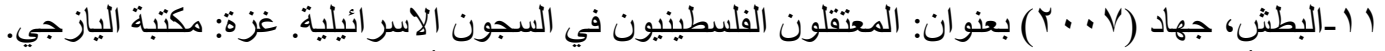

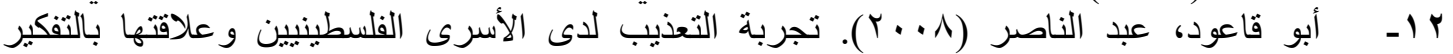

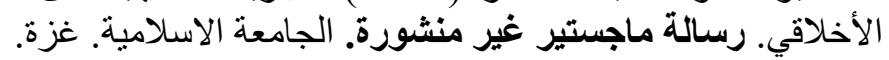

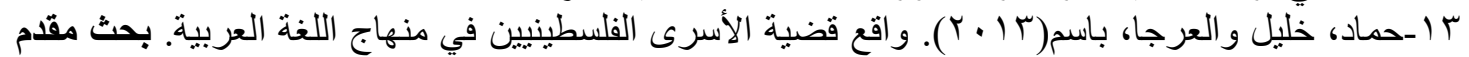

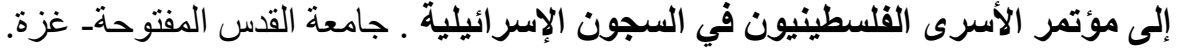

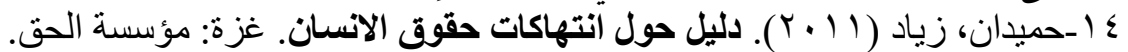

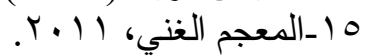

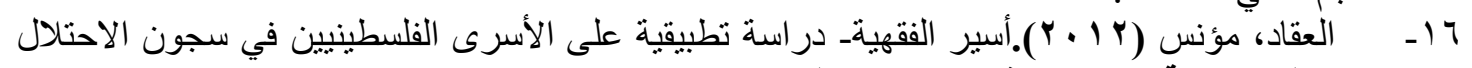

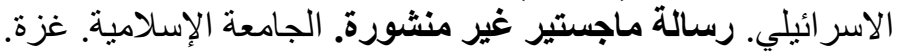

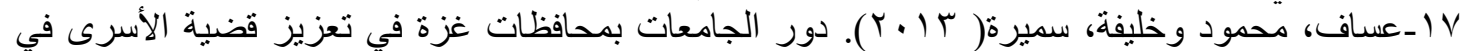

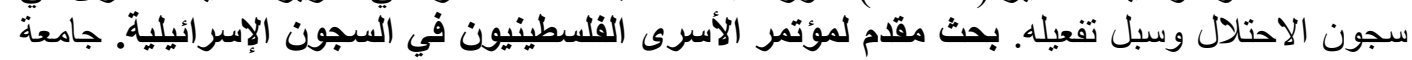
القدس المفتوحة. غزة الاحنل ونيل 